\title{
Vehicle fleet characterization study in the city of Madrid and its application as a support tool in urban transport and air quality policy development
}

\author{
Javier Pérez ${ }^{*}$, Juan Manuel de Andrés, Rafael Borge, David de la Paz, Julio Lumbreras, Encarnación Rodríguez



\section{A R T I C L E I N F O}

\section{Reywords:}

Vehicle fleet characterization

Road traffic enissions

COPERT model: urban traffic

Traffic cameras

Policy-support tool

\begin{abstract}
A B S T R A C T
Road transport is one of the main sources of atmospheric emissions especially in urban areas where exceedances of $\mathrm{NO}_{2}$ or PM limit values are common. This has evident implications regarding health effects and justifies the need to design and apply effective measures to reduce emissions from mobile sources in urban areas. The methodologies to estimate emissions from road transport require, among other relevant factors, a detailed characterization of the actual fleet composition within the city that vehicle registration databases cannot pro vide. This contribution presents an experimental campaign to characterise the fleet of vehicles moving in the city of Madrid (Spain). The field campaign made use of different types of already available traffic cameras in the city to record nearly 5 million license plate readings from 1.3 million different vehicles. This information was used to estimate emissions with the COPERT model in the area of study. According to results obtained, passenger cars are responsible for $80.7 \%$ of the total mileage made in the city and are also the main contributors in terms of emissions ( $65 \%, 73 \%$ and $72 \%$ of $\mathrm{NOx}, \mathrm{CO}_{2}$ and $\mathrm{PM}_{25}$, within mobile sources respectively), mainly due to diesel vehicles that represent $68.2 \%$ of total passenger cars mileage. The study also provided relevant information on average age and other policy relevant details such as average emission factors that should be considered to propose effective emission abatement strategies in Madrid City. A comparison with the information obtained from official registration statistics illustrates the need to perform similar studies to gather accurate information of the actual fleet within a city and thus, design sound measures and policies.
\end{abstract}

\section{Introduction}

Road transportation is one of the most relevant sources of air pol lution in Europe, being responsible for detrimental effects on human health and contributing to climate forcing through greenhouse gases (GHG) emissions and black carbon particles (Curtis et al., 2006; Brunekreef et al., 2009). Although efforts have been made to reduce the emissions from this sector over the last decade, it remains as a sig nificant source of airborne pollutants such as $\mathrm{NO}_{\mathbf{x}}, \mathrm{CO}$ and $\mathbf{P M}_{2.5}$, ac counting for approximately $40 \%, 22 \%$ and $13 \%$, respectively, of the total EU 28 emissions in 2013 (EEA, 2015a). Furthermore, in urban areas these emission shares are usually higher. According to the official emission inventory of the Madrid City (AM, 2015), in 2013 road transport was responsible for $55 \%, 45 \%$ and $62 \%$ of total emissions of $\mathrm{NO}_{x}, \mathrm{CO}$ and $\mathrm{PM}_{2}$, respectively.

In addition to this, complying with the air quality standards estab lished by Directive 2008/50/EC (EU, 2008) remains a challenge for many cities in Europe, constituting a pressing priority for local authorities to address in the 'shortest possible timeframe' (Carslaw et al., 2011; Degraeuwe et al., 2016; EEA, 2015b; Pant and Harrison, 2013; Rexeis and Hausberger, 2009; Williams and Carslaw, 2011). For example, in 2015 many European cities failed to comply with the limit values of $\mathrm{NO}_{2}(\mathrm{EEA}, 2017)$, most often due to the influence of local traffic emissions (up to 90\%, in Madrid City: EEA, 2015b; Borge et al., 2014a, 2014b).

The imminent need of European urban agglomerations to comply with legal air quality standards requires the design and implementation of emission abatement measures that are effective and proportionate within their quality action plans. To this respect, emission inventories constitute an essential instrument for identifying target sectors, as well as using them as input for air quality modelling systems (Borge et al., 2014a, 2014b) able to anticipate the effect of such abatement measures on urban pollution concentration levels. In this sense, the reliability of urban emission inventories is crucial for a correct dimensioning of the abatement effort (Vedrenne et al., 2016).

Therefore, emission inventories should be compiled using the most

\footnotetext{
- Corresponding author.

E-mail address: javier.perez@etsii.upm.es (J. Pérez).
} 
reliable, representative and detailed input data available. In the case of urban road traffic, this implies the need to keep an updated char acterization of the vehicle fleet that circulates within the boundaries of the agglomerations, as well as an accurate mileage data (Ariztegui et al., 2004; Fontes and Pereira, 2014; Franco et al., 2014; Velders et al., 2011). It is worth noting that the vehicles that actually circulate within a particular urban area may be different to those obtained from vehicle registration databases, such as the one provided by the Spain's National Traffic Authority (DGT) (Pujadas et al., 2004). In addition, each type of vehicle can present different annual mileages.

Although this national database holds relevant information about vehicle characteristics (e.g. engine type, weight or age), it should be combined with observations and/or traffic models to estimate the total mileage (measured in vehicles*kilometre, veh*km) by vehicle type (e.g. passenger car, light commercial vehicle, etc.), type of consumed fuel (e.g. gasoline, diesel, etc.) and age distribution (which determines emission standards).

Taking this into account, this paper describes the methodology that was followed to characterise the circulating vehicle fleet of the city of Madrid, in terms of total mileage distribution, based on a license plate survey.

To better establish the novelty and relevance of this work, it is important to consider the differences between the information provided by official vehicle registry (number of vehicles; DGT, 2018) and the data provided by the vehicle fleet characterization (VFC) presented here (distribution of the total mileage made by vehicle type). Some of these differences are:

- official statistics or vehicle registries (DGT, 2018) may be outdated and may include vehicles that have been scrapped

- even in the case where these registries are fully updated, they do not allow discriminating the actual contribution to total mileage (veh*km) of each vehicle type

- official statistics include information regarding where the vehicles are registered but not where are actually driven. In a city like Madrid, a substantial portion of total mileage corresponds to ve hicles that are not registered in the municipality.

The information provided by the VFC allows policy makers tar geting their abatement measures to those vehicle classes with higher mileages or larger emissions and it is therefore more relevant policy wise. In addition, a correct fleet characterization has implications for urban mobility design and traffic management practices. Oppositely, policies informed by emission inventories based on vehicle registries (that is the case for most of the local, regional and national inventories) may be substantially biased since they may propose restrictions on vehicle types that have very reduced significance in terms of total mileage or total emissions (such as very old vehicles with typically very low mileage).

The VFC can also be used integrated in any of the emission com putation methodologies currently available. As an example in this study it was used as input for the COPERT (COmputer Programme to calculate Emissions from Road Transport) emission model (Ntziachristos et al., 2009) to calculate the road traffic emission of airborne pollutants and GHG of the Madrid local emissions inventory (AM, 2015). This in ventory is an essential tool for environmental assessments whose main objectives are:

- estimating the total load of pollutants and GHG emitted to the at mosphere as well as the contribution of the different emission ac tivities to total municipal emissions

- serving as a base for analysing the cost benefits of abatement mea sures and defining policies aimed at pollution minimization

- providing reliable inputs for air quality models (Borge et al., 2014a, 2014b)

- supporting the supervision and control of environmental policies, compliance with standards and objectives and meeting adopted air quality, climate change and energy management targets (AM, 2012a, 2014; 2017)

Nonetheless, the information of the VFC is also useful for other mesoscale emissions models based on traffic situations, as the Handbook Emission Factors for Road Transport, HBEFA (Hausberger et al., 2009; HBEFA, 2010; Borge et al., 2012), microscale models such as the VISSIM VERSIT + micro system (Quaassdorff et al., 2016), or schemes designed to estimate particulate matter resuspension induced by road traffic (de la Paz et al., 2015).

In addition to a more precise emission computation, this work also allowed estimating the age distribution of vehicles as well the regis tration postal code. This information is very useful for policy makers when confronted with the possibility of implementing access restriction policies based on the vehicle age or access/parking bans for non re sidents (Boogaard et al., 2012; Deka, 2012; Ellison et al., 2013; Hammadou and Papix, 2015). Besides contributing to a better under standing of the fleet characteristics in Madrid this case study may be relevant for other cities since the methodology relies on traffic man agement related infrastructure usually available in any medium or large size urban area.

\subsection{COPERT model}

COPERT was selected as emissions model because it is part of the methodology currently used in the inventory of Madrid (AM, 2015) to estimate emissions from road traffic. Despite being routinely used for the compilation of the local inventory, this model has been already implemented and evaluated in many research applications for the me tropolitan area of Madrid (Ariztegui et al., 2004; Borge et al., 2012, 2014a; 2014b; Lumbreras et al., 2008a, 2014; Pujadas et al., 2004; Vedrenne et al., 2014).

COPERT is an average speed model for the estimation of road transport emissions (Ntziachristos and Samaras, 2014) widely used in the compilation of official local, regional and national inventories in Europe as well as a common research tool that includes all main pol lutants: greenhouse gases, air pollutants and toxic species (COPERT, 2018). The development of COPERT is coordinated by the European Energy Agency (EEA) and is part of the EMEP/EEA air pollutant emission inventory guidebook for the calculation of air pollutant emissions (EEA, 2013) and is consistent with the 2006 IPCC Guidelines for the calculation of greenhouse gas emissions.

Its main inputs are vehicle population, mileage made by type of vehicle, percentage of mileage made by driving pattern (highway, rural, urban), average speed and other data such as ambient temperature and fuel specifications. The results of the VFC (main objective of this study) together with data from the municipal traffic model (total mileage made in Madrid City, by zone) were used to calculate mileage made by type of vehicle (COPERT input).

This model estimates emissions from all relevant road vehicle op eration modes: thermal stabilised engine operation ('hot' emissions), the warming up phase ('cold start' emissions) and non exhaust emis sions (from fuel evaporation, tyre and brake wear emissions). It con tains emission factors for more than 450 individual vehicle types in cluding passenger cars, light commercial vehicles, heavy duty vehicles (including trucks and buses) and L category vehicles (including mo peds, motorcycles, quads and mini cars) (COPERT, 2018). Specific emission factors $(\mathrm{g} / \mathrm{km})$ are assigned depending on engine size, fuel type, age, etc. within each category. The methodology developed was designed to produce the information required by COPERT according to this vehicle classification.

\section{Methodology}

The main aim of the experimental campaign was to determine the 
distribution of the total mileage by vehicle type, what is usually re ferred to as "average vehicle".

For this purpose, a license plate reading campaign was conducted to obtain a detailed characterization of the specific circulating vehicle fleet in Madrid. During the field campaign, the license plates of the vehicles passing through a selection of sampling points were captured using already available municipal traffic infrastructure (automatic number plate recognition (ANPR) cameras, such as red light cameras and traffic control cameras). Then, the national vehicle registration database of DGT was used to retrieve all the information needed to assign a COPERT category for each license plate.

\subsection{License plate field campaign}

The license plate capture campaign was carried out from Monday 20th to Monday 27th of May 2013 (both inclusive). The field campaign lasted eight days in order to gather representative information for every day of the week and, therefore avoid any potential deviations in the results arising from differences in the traffic composition between working days and weekends.

\subsubsection{Zoning}

The municipal traffic model divides the road network within Madrid City (represented by broadly 11,000 links) into 5 zones (called A, B, C, $\mathrm{D}$ and $\mathrm{E}$ ), according to their relevance in terms of total mileage, average speed and considering possible differences in the composition of the circulating vehicles. Basically, these 5 zones are determined by the two main ring roads of the city (M30/Calle 30 and M40 both of them highways) (Table 1 and Fig. 1). It was decided to work with the same zoning because the City Council currently defines its measures and plans according to these 5 zones, so the information gathered is con sistent and directly applicable for policymaking within the munici pality.

\subsubsection{Sampling points}

The sampling points (Fig. 1) were selected considering the available municipal resources (ANPR cameras) and trying to get representative information of the vehicles moving through each of the five defined areas. The available municipal resources are:

- Red light cameras of Madrid City Council: located at 17 points within areas A, B, C and E (see Table 2). A total number of $1,180,653$ license plates were collected by these sampling points during the campaign. These cameras are typically used to fine dri vers failing to stop at a red light

- Calle 30 cameras: located at 34 sites, all of them in area B. These sampling points registered 2,987,076 license plates. Cameras nor mally used to control vehicle traffic or to fine drivers exceeding speed limit

- M30 cameras: Two cameras (both in zone B), one located in the Ventas neighbourhood and another at the exit from Costa Rica street. They captured a total number of 476,290 license plates. These two cameras are typically used to fine drivers exceeding speed limit

- Fernández Ladreda square field campaign (zone C). Two sampling points located in Fernández Ladreda Square (Fig. 2) captured

Table 1

Zoning for the vehicle fleet characterization study.

\begin{tabular}{lll}
\hline Zone & Description & average speed $(\mathrm{km} / \mathrm{h})$ \\
\hline A & Inside M30/Calle 30 & 32,1 \\
B & M30/Calle 30 (inner ring road) & 67,7 \\
C & Between M30/Calle 30 and M40 & 49,7 \\
D & M40 (outer ring road) & 85,4 \\
E & Outside M40 & 83,5 \\
\hline
\end{tabular}



Fig. 1. Zoning and location of sampling points.

Table 2

Location of red-light cameras.

\begin{tabular}{lll}
\hline Red light number & Address & Zone \\
\hline 1 & Paseo de la Castellana 167 & $\mathrm{A}$ \\
2 & Cardenal Herrera Oria 83 & $\mathrm{C}$ \\
3 & Hermanos García Noblejas 123 & $\mathrm{C}$ \\
4 & Paseo de la Castellana 105 & $\mathrm{A}$ \\
5 & Poblados - Aluche metro Station & $\mathrm{C}$ \\
6 & Islas Filipinas 18 & $\mathrm{A}$ \\
7 & Ventisquero de la Condesa 42 & $\mathrm{C}$ \\
8 & Logroño - Joaquín Ibarra junction & $\mathrm{E}$ \\
9 & Ilustración - Betanzos junction & $\mathrm{B}$ \\
10 & Andalucía, San Cristóbal metro station & $\mathrm{E}$ \\
11 & Camino de los Vinateros 47 & $\mathrm{C}$ \\
12 & Mediterráneo 32 & $\mathrm{A}$ \\
13 & Menéndez Pelayo - Niño Jesús Hospital & $\mathrm{A}$ \\
14 & Francisco Silvela 62 & $\mathrm{A}$ \\
15 & Cardenal Herrera Oria - Masó junction & $\mathrm{C}$ \\
16 & Fuente Carrantona - Hacienda de Pavones junction & $\mathrm{C}$ \\
17 & Andalucía - Alcocer junction & $\mathrm{E}$ \\
\hline
\end{tabular}

267,723 license plates. The records gathered by these two sampling points originated in another study, as described by Quaassdorff et al. (2016).

It should be noted that no traffic control infrastructure providing information on license plates is available in zone D for this study, be cause this highway is managed by the national government. In addition to this, the high traffic intensity and number of lanes of this road make impossible carrying out any sort of manual sampling. Therefore, it was assumed that the mileage distribution by vehicle type within zone $\mathrm{D}$ was analogous to the one observed in zone B (also highway), due to the lack of a better proxy. The sensibility of this assumption was checked with the only available information provided by DGT for zone D (number of vehicles over and under $7 \mathrm{~m}$ in length). According to these data (around 23 million records), the percentage of vehicles over $7 \mathrm{~m}$ in length accounted for $2.9 \%$ of total vehicles. This figure is rather similar to the share of buses and heavy duty vehicles (HDV) registered in zone B (3\%). 


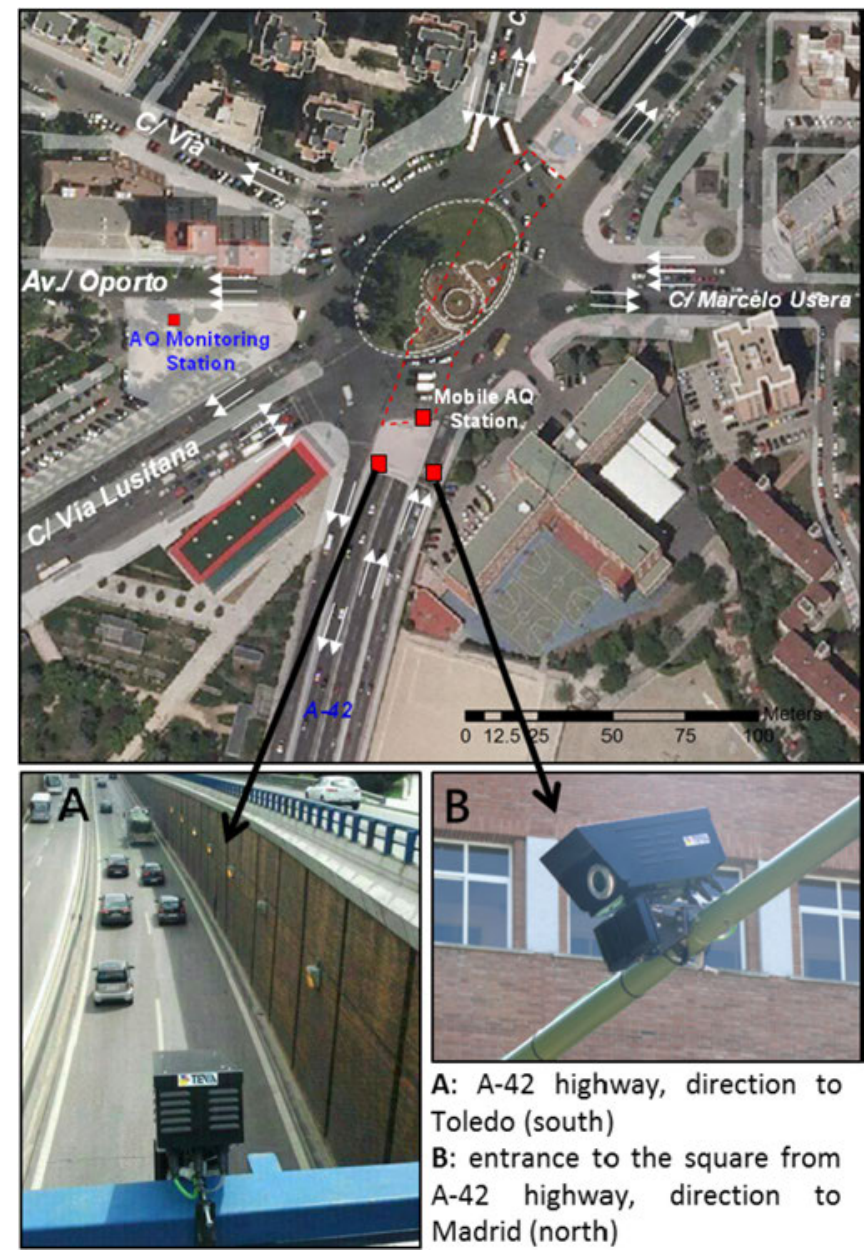

Fig. 2. Cameras in Fernández Ladreda square.

Table 3

Location of manual sampling points.

\begin{tabular}{lll}
\hline Sampling point & Address & Zone \\
\hline 1 & Oporto 35 & $\mathrm{C}$ \\
2 & Alcocer 31-33 & $\mathrm{E}$ \\
3 & San Cipriano 32 & $\mathrm{E}$ \\
4 & Ayacucho - Arequipa junction & $\mathrm{C}$ \\
5 & Logroño 192 & E \\
6 & Albufera 260 & $\mathrm{C}$ \\
7 & Pablo Neruda 30 & $\mathrm{C}$ \\
8 & Gavia 40 & E \\
\hline
\end{tabular}

The campaign was completed between 24th May and 2nd June 2013 with manual samplings at specific locations where further data were deemed necessary. For this purpose, eight additional manual sampling points where located in zones $\mathrm{C}$ and $\mathrm{E}$ (Table 3). At each sampling point, two operators registered the license plates of vehicles in every lane (both directions). These data collection was carried out on a working day (Friday 24th of May) and on a weekend day (Sunday 2nd of June), for a period of approximately half an hour in the morning and in the afternoon. The manual sampling campaign collected a total number of 17,799 records from all 8 sampling points. The collected data are especially interesting to ensure that particular vehicle types, such as mopeds and motorcycles are also included in the sample. For these vehicles, the automatic devices have difficulties reading their li cense plates due to the 'shadow effect' (the obstruction caused by larger vehicles between the camera and the license plate) as well as the fact that the license plates of mopeds are smaller than those of other
Table 4

Manual counting at sampling points with red-light cameras.

\begin{tabular}{llc}
\hline Red light number & Address & Zone \\
\hline 1 & Paseo de la Castellana 167 & $\mathrm{A}$ \\
4 & Paseo de la Castellana 105 & $\mathrm{A}$ \\
6 & IslasFilipinas 18 & $\mathrm{A}$ \\
14 & Francisco Silvela 62 & $\mathrm{A}$ \\
17 & Andalucía - Alcocer junction & $\mathrm{E}$ \\
\hline
\end{tabular}

vehicles and only in the rear.

After a preliminary analysis of the data recorded during the cam paign and based on the sampling points specific features (number of lanes, existence of bus taxi or side lanes), it was decided to extend the additional complementary manual samplings to 5 points where records were previously captured by red light cameras (Table 4). This was needed to fill in gaps and correct biases since some of these devices (which were not originally designed for this purpose) were not re gistering license plates from bus taxi segregated lanes or side lanes.

\subsection{Data cleaning and information retrieval from the national traffic authority (DGT)}

During the field campaign, a total of 4,920,868 license plate read ings were captured as summarized in Table 5. To obtain the vehicle information associated with these license plate numbers, the vehicle registration database managed by DGT was consulted. Before re questing this information, data were checked to eliminate incorrect or incomplete records and to remove duplicates.

After data cleaning, the sample consisted of 1,304,112 single ve hicle registers. The following attributes were obtained for each license plate record: date of first registration, make, model, vehicle type, ser vice (taxi, ambulance, etc.), number of seats, powertrain technology, hybrid flag (yes/no), engine size, maximum weight, postcode of the vehicle and postcode of the owner.

It should be noted that the exclusion of duplicate records was only carried out in order to interrogate the DGT database. However, all re cords (including duplicates) were considered in the study to obtain the VFC.

\subsection{Vehicle classification and information processing}

The next step consisted of establishing the necessary correspon dence between each of the license plate readings and the vehicle type classification included in the EMEP/EEA methodology (EEA, 2013). As explained in the introduction, this methodology involves the COPERT model, that classifies vehicles according to three hierarchical levels (Table 6):

- Sector: passenger cars, light commercial vehicles (LCV), HDV, buses, motorcycles and mopeds

- Subsector: disaggregation of each sector as follows:

Table 5

Sample summary.

\begin{tabular}{llll}
\hline Sampling source & $\begin{array}{l}\text { Number of } \\
\text { sampling points }\end{array}$ & Zone & Number of records \\
\hline Red-light cameras & 17 & $\begin{array}{l}\text { A, B, C } \\
\text { and E }\end{array}$ & $1,180,653$ \\
Calle 30 cameras & 34 & B & $2,987,076$ \\
M30 cameras & 2 & B & 476,290 \\
Fernández Ladreda Sq & 2 & C & 267,723 \\
$\quad$ cameras & 8 & C and E & 17,799 \\
$\begin{array}{l}\text { Manual sampling } \\
\text { TOTAL }\end{array}$ & $\mathbf{6 3}$ & $\begin{array}{l}\text { A, B, C } \\
\text { and E }\end{array}$ & $\mathbf{4 , 9 2 0 , 8 6 8}$ \\
& & & \\
\hline
\end{tabular}


Table 6

DGT attributes used to assign COPERT levels.

\begin{tabular}{ll}
\hline COPERT level & DGT attributes \\
\hline Sector & vehicle type \\
& number of seats \\
maximum weight & powertrain \\
Subsector & engine size (engine displacement) \\
& maximum weight \\
& hybrid flag \\
& make \\
& model \\
date of first registration & \\
\hline
\end{tabular}

- passenger cars are disaggregated by fuel and engine size,

- LCV and HDV by fuel and weight,

- buses by weight,

- motorcycles and mopeds by engine size

- Technology: vehicles within each subsector are separated according to emission reduction technologies (EURO standards).

It should be noted that the classification used for this study is more detailed than that of COPERT. Any vehicle types susceptible of being targeted by specific policies and mitigation measures to reduce their atmospheric emissions, were explicitly considered: such as municipal solid waste collection and transport fleet (López et al., 2009; Pérez et al., 2017), taxis (Vedrenne et al., 2014), municipal buses (García et al., 2012), etc. Amongst these vehicle types, taxis and buses are especially relevant due to their high mileage (particularly in city cen tres). The specific processing for this categories is explained below.

\subsubsection{Processing data from taxis}

In order to segregate 'taxis' within 'passenger cars' the DGT 'service' attribute was used in this instance.

Some fields such as 'date of first registration', 'make', 'model' and 'hybrid flag' of the subsample obtained where contrasted with the specific information on this sector provided by the Taxi Department (total number of municipal taxi vehicles by year and its distribution by fuel, engine size and EURO standard.) and the specific taxi regulation in the city of Madrid (AM, 2012b) to avoid any possible inconsistency.

\subsubsection{Processing data from buses}

From the transport management point of view is relevant to dif ferentiate vehicles operated by public or private companies. The Municipal Transport Company of Madrid (EMT) provided detailed in formation about:

- number of buses on each line and total mileage

- routes of the different lines (Fig. 3)

- license plate number, fuel and emission standard (Euro) of every single vehicle.

This information was used to complete readings for those 5 sam pling points where segregated lanes were not properly covered by red light cameras (Table 4). It also allowed splitting the COPERT sector 'buses' into 'EMT buses' and 'non EMT buses', and therefore differ entiate between emissions from a segment of vehicles dependent on Madrid City Council (for which specific measures can be adopted), and those produced by other types of buses (such as regional, occasional buses and coaches).

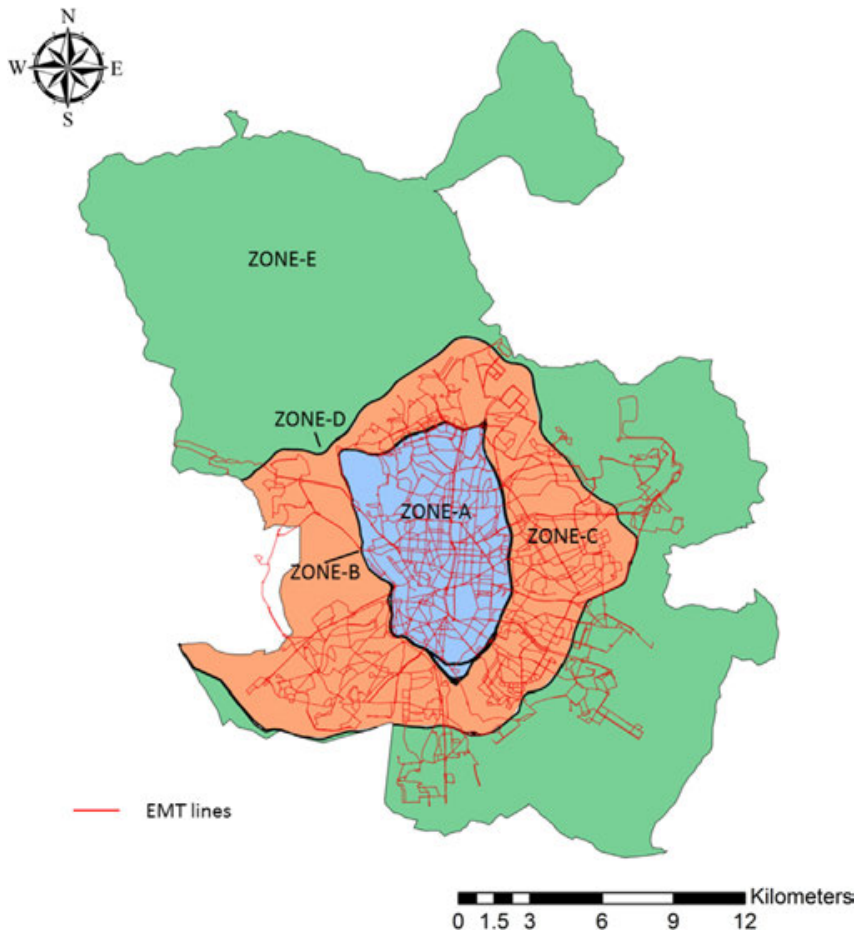

Fig. 3. Madrid Municipal Transport Company (EMT) bus lines.

\subsection{Integration of manual sampling}

Data from manual samplings (8 initial samplings plus 5 manual counting points at red light cameras locations), together with detailed information of EMT buses, were used to complete fleet compositions by sector at sampling point level. This process allowed incorporating mopeds and correcting the deviations of some ANPR cameras records (section 2.1.2).

\subsection{Geographic data aggregation}

\subsubsection{Aggregation at zone level}

Once individual readings were processed, data collected in sampling points within the same zone were aggregated in order to obtain a composition of the vehicle fleet (average vehicle) at zone level (A to E), as they have been defined in section 2.1.1. This process of aggregation considered the following hypotheses and assumptions:

- homogeneous composition of road traffic within each of the five zones;

- not weighting between sampling points or between type of vehicles within a zone, that is, the mileage of a vehicle whose license number has been registered at any sampling point is assumed to be the same within each zone;

- the mileage of a given vehicle type within each zone is directly proportional to the number of records of that vehicle type in that zone;

- fleet composition in zone D is assumed to be the same than that in zone $\mathrm{B}$, as explained in section 2.1.2.

\subsubsection{Aggregation at municipal level}

The so called 'average vehicle' for the whole municipality was ob tained as an average of the vehicle composition by zone weighted by the total mileage made within each of the 5 different zones. Total mileage is taken from the municipal traffic demand model. According to this model, the distribution of total mileage $(11,967,752,667 \mathrm{veh} * \mathrm{~km} /$ year in 2013) by zones in 2013 were: $21.1 \%$ zone A, $11.7 \%$ zone B, 


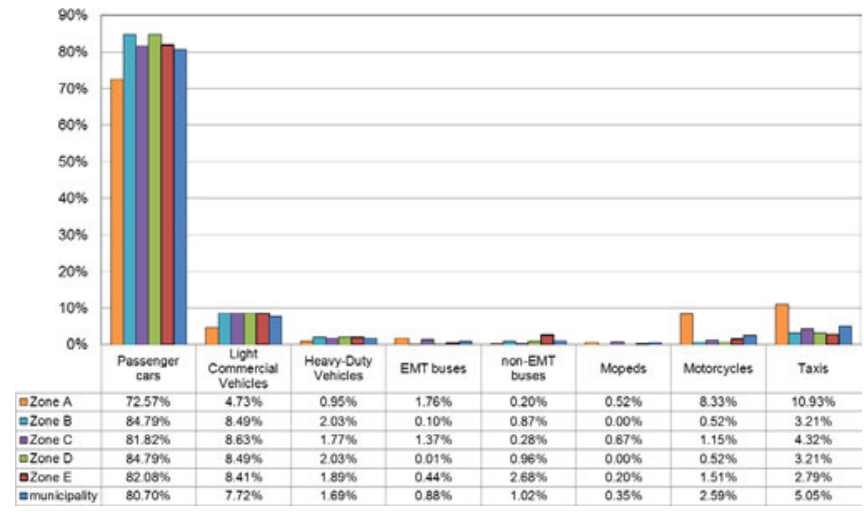

Fig. 4. Composition of the 'average vehicle' (share of veh*km) in Madrid.

$28.6 \%$ zone C, $14.1 \%$ zone D, and $24.5 \%$ zone E.

\section{Results}

This section describes the results of the VFC methodology and its application to calculate the road traffic emissions in Madrid.

\subsection{The 'average vehicle'}

Fig. 4 shows the composition of the 'average vehicle' at sector level for each zone and for the entire municipality. Although not shown, this information can be further disaggregated at COPERT subsector and technology level. A fully detailed description of the 'average vehicle' according to this study can be found in Appendix A.

As it can be observed, passenger cars are responsible for $80.7 \%$ of the total mileage made in the municipality. The following vehicle types in importance in terms of mileage are LCV and taxis, accounting for 7.7 and $5.1 \%$, respectively. The contribution of the remaining sectors combined is below $3 \%$.

It can be seen that the 'average vehicle' of zones $\mathrm{B}$ to $\mathrm{E}$ are quite similar. However, within zone A (city centre, inside Calle 30/M30), the contributions to the total mileage of passenger cars (72.6\%), LCV and HDV decrease while those of motorcycles, buses and taxis increase.

As shown in Table 7, most passenger cars circulating within Madrid city are diesel vehicles, representing $55.1 \%$ of the total mileage made ( $68.2 \%$ of the mileage of passenger cars), compared with the $25.6 \%$ of gasoline cars (31.7\% of the mileage of passenger cars). Electric, hybrid and alternative fuelled passenger cars (compressed natural gas, CNG, or liquefied petroleum gas, LPG), account for less than $0.1 \%$ of the total mileage of passenger cars. Excluding mopeds and motorcycles, which typically use gasoline, the rest of vehicle types are also mainly diesel fuelled.

A comparison between these results and the distribution of the number of vehicles per type and fuel according to the official vehicle registration database (DGT, 2018), is shown in Table 8. Significant differences are observed between the distributions in terms of mileage made. However, the most remarkable difference is related to the dis tribution of mileage by fuel, both for passenger cars/taxis and for the whole vehicles fleet. Overall, gasoline vehicles would represent nearly $53 \%$ of total mileage according to the registration database while they actually account for less than $29 \%$. These results are illustrative of the errors that can be introduced when emission estimations are based on official statistics that do not represent the actual fleet composition.

\subsubsection{Fleet age}

According to the results, the average age of a passenger cars is 9.3 years (7.2 for diesel, 13.0 for gasoline and 6.8 for others), 10.0 years for LCV, 10.8 years for HDV, 8.1 years for buses, 9.8 years for motorcycles and 4.4 years for taxis. The cumulative age distribution for passenger cars is shown in Fig. 5, which provides valuable information to generate emission projections (Beser Hugosson et al., 2017; Lumbreras et al., 2014, 2008a, b) and also for the design of emission reduction policies and mitigation scenarios, mainly access restriction to some areas or low emission zones (LEV), based on vehicles age (Boogaard et al., 2012; Ellison et al., 2013; Hammadou and Papix, 2015; Vedrenne et al., 2014).

\subsubsection{Distribution by postcode}

An analysis of the origin of the vehicles moving through the city, using the 'postcode of the vehicle's owner attribute (DGT) may also provide relevant information for the elaboration of policies, such as the implementation of traffic restriction measures or parking restrictions for non residents (Deka, 2012).

Fig. 6 shows aggregated results by postcodes: municipality of Ma drid, other municipalities in the Madrid's region and other provinces. The results point out that only $53.4 \%$ of mileage within the city boundary is made by drivers registered in the municipality of Madrid.

\subsection{Road traffic emissions estimation}

Emissions were estimated with COPERT using the fleet character ization previously described and the information from the municipal traffic model (providing total mileage and average speed by zone) as discussed in the methodology. The rest of parameters required by COPERT are provided by municipal meteorological statistics (maximum and minimum temperatures) and national regulations (e.g. fuels spe cifications as sulphur and metals content, vapour pressure of gasolines, etc.).

Fig. 7 shows the resulting share of $\mathrm{NOx}, \mathrm{CO}_{2}$ and $\mathrm{PM}_{2.5}$ emissions by vehicle type along with total mileage figures. This is relevant to discuss not only total contributions by vehicle type but specific emissions (by distance travelled) for each of them. It can be observed that passenger cars are the main contributors in terms of emissions, accounting for 65, 73 and $72 \%$ of $\mathrm{NOx}, \mathrm{CO}_{2}$ and $\mathrm{PM}_{2.5}$, respectively. However, the con tribution of this sector to road traffic emissions is lower than the con tribution to total mileage (81\%), since they have lower emission factors (EF) $(\mathrm{g} / \mathrm{km})$ in comparison to other vehicle types, such as HDV and buses. Aggregated $\mathrm{EF}$ for $\mathrm{NOx}$ and $\mathrm{CO}_{2}$ (total emissions/total mileage, by vehicle type) are illustrated in Fig. 8 .

The taxi sector, accounting for $5 \%$ of total mileage, is responsible for around $4 \%$ of $\mathrm{NOx}$ and $\mathrm{CO}_{2}$ emissions and for $5 \%$ of $\mathrm{PM}_{2.5}$ emis sions. The ratio emissions/mileage of this vehicle type is slightly dif ferent to the one of passenger cars, as a result of a higher contribution of diesel fuelled vehicles to the total vehicle type mileage (78 versus $68 \%$ for passenger cars) and the lower average age (4.4 versus 9.3 years). According to the results, taxis are slightly more efficient in terms of consumption and $\mathrm{CO}_{2}$ emissions (5.6\%) than the average passenger car but present a very similar $\mathrm{NO}_{\mathrm{X}}$ emission rate $(0.7 \%$ higher $)$.

LCV account for $8 \%$ of total mileage but are responsible for 11,9 and $14 \%$ of $\mathrm{NOx}, \mathrm{CO}_{2}$ and $\mathrm{PM}_{2.5}$, respectively. These results are strongly conditioned by the type of fuel consumed (Lozhkina and Lozkhin, 2016) and vehicle age (Pandey et al., 2016), which determines emission standards. This type of vehicle presents a larger diesel share and an average age of 10 years, versus 9.3 or 4.4 of passenger cars and taxis, respectively. As a result of both factors, the EF for NOx is remarkably higher (Fig. 8) than that of passenger cars and taxis (broadly $70 \%$ higher). This issue may have important implications that would need to be considered when designing specific measures for freight distribution activities.

The EMT buses only represent around $1 \%$ of municipal mileage but account for 7.5, 4.6 and $2.7 \%$ of $\mathrm{NOx}, \mathrm{CO}_{2}$ and $\mathrm{PM}_{2,5}$ emissions. Despite the important penetration of natural gas in this particular fleet sector (around 45\%), which reduces $\mathrm{NOx}, \mathrm{CO}_{2}$ and $\mathrm{PM}_{2,5}$ emissions in relation to diesel heavy duty/bus vehicles, aggregated emission factors are still higher than the rest of vehicles (Alam and Hatzopoulou, 2014; Fontaras 
Table 7

Disaggregation of 'average vehicle' by vehicle and fuel type for each zone.

\begin{tabular}{|c|c|c|c|c|c|c|}
\hline \multirow[t]{2}{*}{ Sector } & \multicolumn{6}{|l|}{ Zones } \\
\hline & A & B & $\mathrm{C}$ & $\mathrm{D}$ & $\mathrm{E}$ & TOTAL Municipality \\
\hline Passenger cars & $72.57 \%$ & $84.79 \%$ & $81.82 \%$ & $84.79 \%$ & $82.08 \%$ & $80.70 \%$ \\
\hline Gasoline & $25.21 \%$ & $25.79 \%$ & $25.10 \%$ & $25.79 \%$ & $26.21 \%$ & $25.57 \%$ \\
\hline Diesel & $47.29 \%$ & $58.94 \%$ & $56.67 \%$ & $58.94 \%$ & $55.83 \%$ & $55.08 \%$ \\
\hline Others (LPG, CNG, hybrids. electric) & $0.07 \%$ & $0.06 \%$ & $0.05 \%$ & $0.06 \%$ & $0.04 \%$ & $0.05 \%$ \\
\hline Light commercial vehicles & $4.73 \%$ & $8.49 \%$ & $8.63 \%$ & $8.49 \%$ & $8.41 \%$ & $7.72 \%$ \\
\hline Gasoline & $0.15 \%$ & $0.33 \%$ & $0.23 \%$ & $0.33 \%$ & $0.22 \%$ & $0.24 \%$ \\
\hline Diesel & $4.58 \%$ & $8.15 \%$ & $8.40 \%$ & $8.15 \%$ & $8.19 \%$ & $7.48 \%$ \\
\hline Others (LPG, CNG, hybrids, electric) & $0.00 \%$ & $0.00 \%$ & $0.00 \%$ & $0.00 \%$ & $0.00 \%$ & $0.00 \%$ \\
\hline Heavy-duty vehicles & $0.95 \%$ & $2.03 \%$ & $1.77 \%$ & $2.03 \%$ & $1.89 \%$ & $1.69 \%$ \\
\hline Gasoline & $0.01 \%$ & $0.01 \%$ & $0.01 \%$ & $0.01 \%$ & $0.01 \%$ & $0.01 \%$ \\
\hline Diesel & $0.94 \%$ & $2.01 \%$ & $1.76 \%$ & $2.01 \%$ & $1.88 \%$ & $1.68 \%$ \\
\hline Buses & $1.96 \%$ & $0.97 \%$ & $1.64 \%$ & $0.97 \%$ & $3.12 \%$ & $1.90 \%$ \\
\hline EMT buses & $1.76 \%$ & $0.10 \%$ & $1.37 \%$ & $0.01 \%$ & $0.44 \%$ & $0.88 \%$ \\
\hline Diesel & $0.96 \%$ & $0.08 \%$ & $1.02 \%$ & $0.01 \%$ & $0.41 \%$ & $0.60 \%$ \\
\hline Others (LPG, CNG, hybrids, electric) & $0.80 \%$ & $0.02 \%$ & $0.35 \%$ & $0.00 \%$ & $0.02 \%$ & $0.28 \%$ \\
\hline non-EMT buses & $0.20 \%$ & $0.87 \%$ & $0.28 \%$ & $0.96 \%$ & $2.68 \%$ & $1.02 \%$ \\
\hline Diesel & $0.18 \%$ & $0.87 \%$ & $0.28 \%$ & $0.95 \%$ & $2.56 \%$ & $0.99 \%$ \\
\hline Others (LPG, CNG, hybrids, electric) & $0.02 \%$ & $0.00 \%$ & $0.00 \%$ & $0.01 \%$ & $0.12 \%$ & $0.03 \%$ \\
\hline Mopeds & $0.52 \%$ & $0.00 \%$ & $0.67 \%$ & $0.00 \%$ & $0.20 \%$ & $0.35 \%$ \\
\hline Gasoline & $0.52 \%$ & $0.00 \%$ & $0.67 \%$ & $0.00 \%$ & $0.20 \%$ & $0.35 \%$ \\
\hline Motorcycles & $8.33 \%$ & $0.52 \%$ & $1.15 \%$ & $0.52 \%$ & $1.51 \%$ & $2.59 \%$ \\
\hline Gasoline & $8.33 \%$ & $0.52 \%$ & $1.15 \%$ & $0.52 \%$ & $1.51 \%$ & $2.59 \%$ \\
\hline Taxis $^{\mathrm{a}}$ & $10.93 \%$ & $3.21 \%$ & $4.32 \%$ & $3.21 \%$ & $2.79 \%$ & $5.05 \%$ \\
\hline Diesel & $8.48 \%$ & $2.47 \%$ & $3.37 \%$ & $2.47 \%$ & $2.22 \%$ & $3.93 \%$ \\
\hline Others (LPG, CNG, hybrids, electric) & $2.46 \%$ & $0.74 \%$ & $0.95 \%$ & $0.74 \%$ & $0.57 \%$ & $1.12 \%$ \\
\hline TOTAL & $100.00 \%$ & $100.00 \%$ & $100.00 \%$ & $100.00 \%$ & $100.00 \%$ & $100.00 \%$ \\
\hline Gasoline & $34.22 \%$ & $26.65 \%$ & $27.16 \%$ & $26.65 \%$ & $28.15 \%$ & $28.76 \%$ \\
\hline Diesel & $62.43 \%$ & $72.53 \%$ & $71.49 \%$ & $72.54 \%$ & $71.10 \%$ & $69.76 \%$ \\
\hline Others (LPG, CNG, hybrids, electric) & $3.35 \%$ & $0.82 \%$ & $1.35 \%$ & $0.81 \%$ & $0.76 \%$ & $1.48 \%$ \\
\hline
\end{tabular}

${ }^{\text {a }}$ Dual Gasoline-LPG taxis are considered to be LPG.

et al., 2012; Jayaratne et al., 2010, 2009; Nanaki et al., 2017, 2014; Pastorello et al., 2011; Pérez et al., 2017; Rose et al., 2013; Sandhu et al., 2014; Suthawaree et al., 2012).

The contribution of the remaining vehicle types to road traffic emissions is below $5 \%$. However, the contribution of HDV and non EMT buses to the emissions is higher than their contribution to the total mileage, while mopeds and motorcycles present the opposite trend, as a results of their lower EF per veh*km (Fig. 8).

As explained in the introductory section, Madrid, as many other cities in Europe (EEA, 2017), fails to comply with the $\mathrm{NO}_{2}$ concentra tion limit values in ambient air (AM, 2016 and previous annual air quality assessment reports). The primary $\mathrm{NO}_{2} / \mathrm{NO}_{\mathrm{X}}$ ratio is an im portant factor regarding $\mathrm{NO}_{2}$ ambient air concentration measured at traffic air quality monitoring stations, so it is also relevant to scrutinize $\mathrm{NO}_{\mathrm{X}}$ emission speciation.

Fig. 9 shows the contribution of each sector to municipal road traffic emissions, distinguishing between primary $\mathrm{NO}$ and $\mathrm{NO}_{2}$. The emission share of passenger cars is even larger for primary $\mathrm{NO}_{2}(72.8 \%)$ than for

Table 8

Comparison between the obtained results in VFC study and the distribution by number of vehicles according to national vehicle registration database (data for Madrid City in 2013).

\begin{tabular}{|c|c|c|}
\hline & $\begin{array}{l}\text { VFC } 2013 \text { study. \% in terms of mileage } \\
\text { made }\end{array}$ & $\begin{array}{l}\text { Vehicle registration database (DGT database, Madrid City). \% in terms of } \\
\text { number of vehicles }\end{array}$ \\
\hline Passenger cars + Taxis & $85,75 \%$ & $76,95 \%$ \\
\hline Gasoline & $25,57 \%$ & $39,65 \%$ \\
\hline Diesel & $59,01 \%$ & $37,27 \%$ \\
\hline Others (LPG, CNG, hybrids. electric) & $1,17 \%$ & $0,03 \%$ \\
\hline Light commercial vehicles + Heavy duty vehicles & $9,41 \%$ & $11,38 \%$ \\
\hline Gasoline & $0,25 \%$ & $1,77 \%$ \\
\hline Diesel & $9,16 \%$ & $9,59 \%$ \\
\hline Others (LPG, CNG, hybrids, electric) & $0,002 \%$ & $0,014 \%$ \\
\hline Buses & $1,90 \%$ & $0,33 \%$ \\
\hline Gasoline & $0,00 \%$ & $0,00 \%$ \\
\hline Diesel & $1,59 \%$ & $0,30 \%$ \\
\hline Others (LPG, CNG, hybrids, electric) & $0,31 \%$ & $0,03 \%$ \\
\hline Mopeds & $0,35 \%$ & $2,45 \%$ \\
\hline Gasoline & $0,35 \%$ & $2,45 \%$ \\
\hline Motorcycles & $2,59 \%$ & $8,89 \%$ \\
\hline Gasoline & $2,59 \%$ & $8,89 \%$ \\
\hline TOTAL & $100,00 \%$ & $100,00 \%$ \\
\hline Gasoline & $28,76 \%$ & $52,76 \%$ \\
\hline Diesel & $69,76 \%$ & $47,16 \%$ \\
\hline Others (LPG, CNG, hybrids, electric) & $1,48 \%$ & $0,08 \%$ \\
\hline
\end{tabular}

Dual Gasoline-LPG taxis are considered to be LPG. 


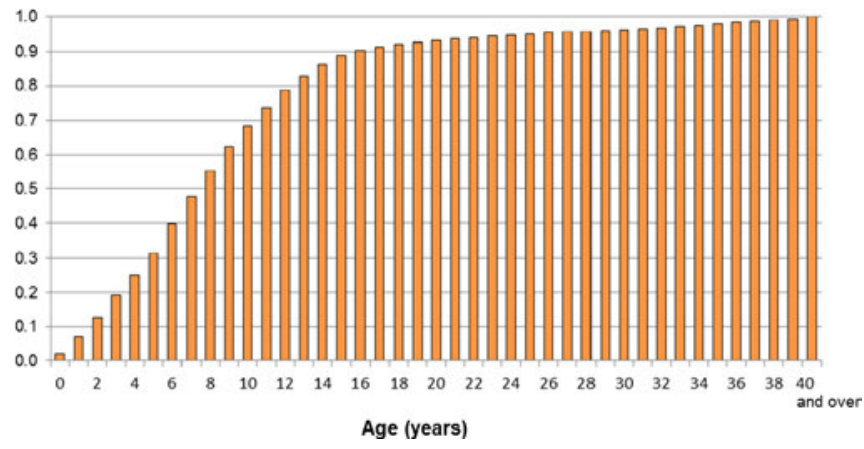

Fig. 5. Age distribution (cumulative frequency) of passenger cars.



Fig. 6. Breakdown of passenger cars by postcode.

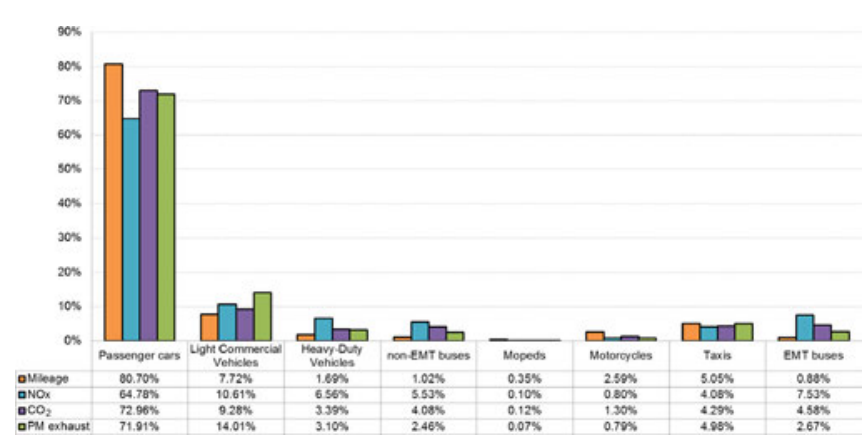

Fig. 7. Emissions distribution by vehicle type.

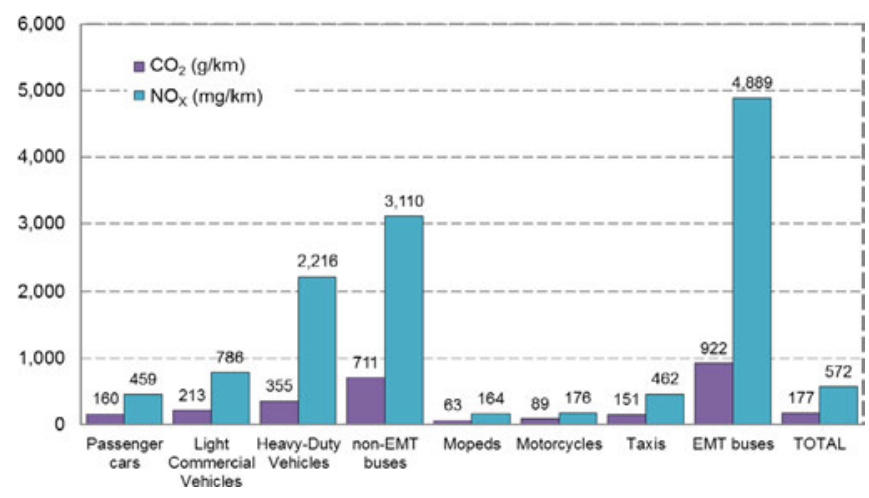

Fig. 8. NOx $(\mathrm{mg} / \mathrm{km})$ and $\mathrm{CO}_{2}(\mathrm{~g} / \mathrm{km})$ aggregated emission factor by vehicle type.

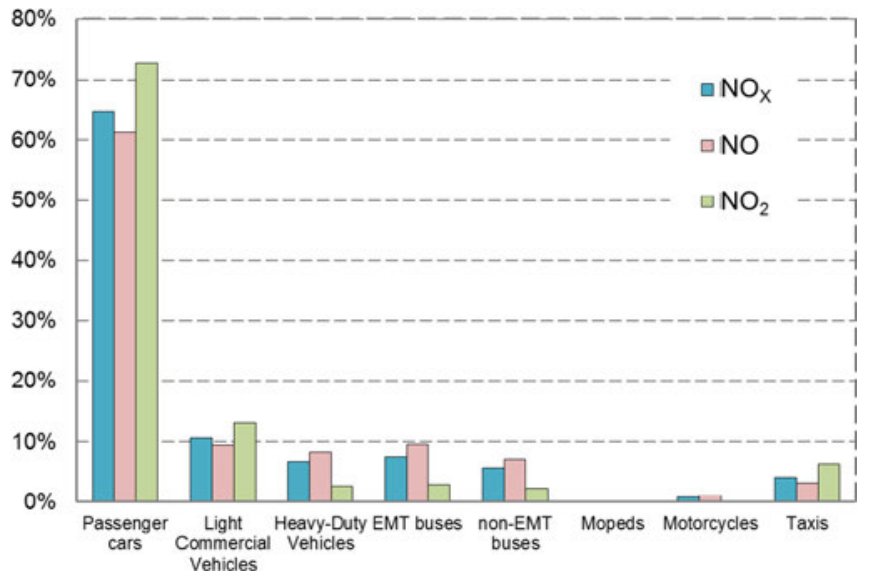

Fig. 9. Contribution to road transport $\mathrm{NOx}, \mathrm{NO}$ and $\mathrm{NO}_{2}$ emissions by vehicle type.

Table 9

Emission share of passenger cars by fuel.

\begin{tabular}{|c|c|c|c|c|c|c|}
\hline Fuel & Mileage & NOx & NO & $\mathrm{NO}_{2}$ & $\mathrm{PM}_{2.5}$ & $\mathrm{CO}_{2}$ \\
\hline \multicolumn{7}{|c|}{ Respect to passenger cars } \\
\hline Passenger cars & $100.0 \%$ & $100.0 \%$ & $100.0 \%$ & $100.0 \%$ & $100.0 \%$ & $100.0 \%$ \\
\hline Gasoline & $31.7 \%$ & $13.5 \%$ & $19.9 \%$ & $1.5 \%$ & $11.6 \%$ & $34.2 \%$ \\
\hline Diesel & $68.2 \%$ & $86.5 \%$ & $80.1 \%$ & $98.5 \%$ & $88.4 \%$ & $65.8 \%$ \\
\hline Hybrids \& electric & $0.05 \%$ & $0.00 \%$ & $0.00 \%$ & $0.00 \%$ & $0.01 \%$ & $0.02 \%$ \\
\hline Others (LPG, CNG) & $0.01 \%$ & $0.00 \%$ & $0.00 \%$ & $0.00 \%$ & $0.00 \%$ & $0.01 \%$ \\
\hline \multicolumn{7}{|c|}{ Respect to total road traffic } \\
\hline Passenger cars & $80.7 \%$ & $64.8 \%$ & $61.2 \%$ & $72.8 \%$ & $72.2 \%$ & $73.0 \%$ \\
\hline Gasoline & $25.6 \%$ & $8.8 \%$ & $12.2 \%$ & $1.1 \%$ & $8.4 \%$ & $25.0 \%$ \\
\hline Diesel & $55.1 \%$ & $56.0 \%$ & $49.0 \%$ & $71.7 \%$ & $63.8 \%$ & $48.0 \%$ \\
\hline Hybrids \& electric & $0.04 \%$ & $0.00 \%$ & $0.00 \%$ & $0.00 \%$ & $0.01 \%$ & $0.02 \%$ \\
\hline Others (LPG, CNG) & $0.01 \%$ & $0.00 \%$ & $0.00 \%$ & $0.00 \%$ & $0.00 \%$ & $0.01 \%$ \\
\hline
\end{tabular}

NOx (64.8\%). It can be explained by the increase of $\mathrm{NO}_{2} / \mathrm{NOx}$ emissions ratio in newer (Euro 4 and 5) diesel technologies (Alvarez et al., 2008; Carslaw et al., 2011). This ratio is higher in passenger cars and LCV than in other sectors such as HDV or buses (COPERT).

Further details regarding emissions by fuel are shown in Table 9. It can be seen that emissions from passenger cars are clearly dominated by diesel vehicles (e.g. $86.5 \%$ of $\mathrm{NOx}$ and $88.4 \%$ of $\mathrm{PM}_{2.5}$ emissions). However, the contribution of diesel fuelled cars to $\mathrm{NO}_{2}$ emissions is even larger, reaching $98.5 \%$ (71.7\% of total road traffic emissions). The contribution of gasoline cars to $\mathrm{CO}_{2}$ emissions (34.2\%) is higher than that to the air quality pollutants (and total mileage, 31.7\%) because $\mathrm{CO}_{2}$ emissions are mainly related to fuel consumption rate (litres $/ \mathrm{km}$ ), which is higher for gasoline than diesel vehicles.

\section{Conclusions}

This study presents the methodology followed to obtain the vehicle fleet characterization (VFC) of a city with the help of the available municipal resources. This type of studies provides essential information to design policies and measures aimed at improving mobility and air quality. In this work, the VFC of the city of Madrid is used to understand the fleet composition and to estimate the local road traffic emissions.

According to the results obtained (from a total number of 4,920,868 license plate readings), the passenger cars sector is responsible for $80.7 \%$ of the total mileage made in the municipality of Madrid, fol lowed by light commercial vehicles and taxis, accounting for $7.7 \%$ and $5.1 \%$ of total mileage, respectively. A comparison with the information provided by the official national registration database shows important discrepancies, mainly regarding the mileage share of gasoline/diesel vehicles. This highlights the importance of estimating traffic road emissions considering the vehicles that actually circulate within the city 
instead of using data provided by vehicle registration databases.

The vehicle fleet characteristics are quite similar in all the zones of the city, except in the city centre, with a larger proportion of motor cycles, buses and taxis. The VFC and the estimation of emissions by zone allow estimating and implementing specific measures for those zones where air quality problems are more evident, such as the estab lishment of low emission zones.

The information provided by this study may be extremely useful in the implementation of a wide range of measures aimed at improving air quality in cities, such as: i) access restrictions based on vehicle age, technology, and/or fuel, for which the information presented in section 3.1.1 is essential; ii) access or parking restrictions for non residents, which can be informed with the results presented in section 3.1.2, where the origin of the vehicles moving through the city is analysed. These two type of measures are currently considered in the recently adopted Air Quality Plan of the city of Madrid (Plan A, 2020 time horizon).

In Madrid, all vehicle types are mainly diesel fuelled, with the ex ception of mopeds and motorcycles, which typically use gasoline, as well as municipal buses, that present a natural gas share as high as $45 \%$. The contribution of diesel vehicles to total mileage accounts for $69.8 \%$. Passenger cars are the major emitters in Madrid, accounting for 65, 73 and $72 \%$ of $\mathrm{NOx}, \mathrm{CO}_{2}$ and $\mathrm{PM}_{2.5}$, of total road traffic emissions, re spectively. The contribution of this type of vehicles to $\mathrm{NO}_{2}$ emissions is even higher (72\%), due to the increase of $\mathrm{NO}_{2} / \mathrm{NOx}$ emissions ratio in newer (Euro 4 and 5) diesel technologies. Knowing the types of vehicles that show the highest contributions to total emissions allow a correct design of measures aimed at tackling air pollution and climate change. While providing very relevant information at a very reduced cost, this methodology to assess the VFC also presents limitations:

- the number and the location of municipal resources (cameras) that can be used as sampling points may condition the representativeness of the sample

- the use of the municipal resources is limited in time, since they are normally used to control vehicle traffic or to fine drivers exceeding speed limit

- capture devices may have arbitrary reading errors and requires an intensive data depuration process

- it requires the involvement of a large number of local, regional and national authorities (and an appropriate coordination among their different departments)

Future editions of VFC studies and future research lines should be aimed at:

- improving the number and locations of sampling points used to obtain the VFC

- carrying out an uncertainty analysis, with the compilation of a greater number of data

- developing procedures to integrate this methodology in routinely emission computation and air quality modelling systems so it can provide a better support for the assessment of specific road traffic measures on air quality.

\section{Acknowledgements}

This study was funded by the Madrid City Council (General Direction of Traffic Management Environment and Mobility Area) in the scope of the Madrid Emission Inventory (300/2012/00489). Collaboration of the Spain's national traffic authority (Dirección General de Tráfico, DGT), the Municipal Transport Company (EMT, S.A) and Madrid Calle 30, S.A. was essential for the development of this work. The authors also thank the reviewers for their fruitful comments.

Appendix A. Disaggregation of the 'average vehicle' (percentage of veh*km) by COPERT sector, subsector and technology

\begin{tabular}{|c|c|c|c|c|c|c|c|c|}
\hline Sector & Subsector & Technology & Zone A & Zone B & Zone C & Zone D & Zone E & Total \\
\hline Passenger Cars & Gasoline $<0.81$ & PRE ECE & $0.00 \%$ & $0.00 \%$ & $0.00 \%$ & $0.00 \%$ & $0.00 \%$ & $0.00 \%$ \\
\hline Passenger Cars & Gasoline $<0.81$ & ECE 15/00-01 & $0.01 \%$ & $0.05 \%$ & $0.03 \%$ & $0.05 \%$ & $0.02 \%$ & $0.03 \%$ \\
\hline Passenger Cars & Gasoline $<0.81$ & ECE $15 / 02$ & $0.00 \%$ & $0.01 \%$ & $0.00 \%$ & $0.01 \%$ & $0.00 \%$ & $0.01 \%$ \\
\hline Passenger Cars & Gasoline $<0.81$ & ECE $15 / 03$ & $0.00 \%$ & $0.01 \%$ & $0.00 \%$ & $0.01 \%$ & $0.00 \%$ & $0.00 \%$ \\
\hline Passenger Cars & Gasoline $<0.81$ & ECE 15/04 & $0.00 \%$ & $0.00 \%$ & $0.00 \%$ & $0.00 \%$ & $0.00 \%$ & $0.00 \%$ \\
\hline Passenger Cars & Gasoline $<0.81$ & PC Euro 1-91/441/EEC & $0.00 \%$ & $0.00 \%$ & $0.00 \%$ & $0.00 \%$ & $0.00 \%$ & $0.00 \%$ \\
\hline Passenger Cars & Gasoline $<0.81$ & PC Euro 2-94/12/EEC & $0.03 \%$ & $0.02 \%$ & $0.03 \%$ & $0.02 \%$ & $0.02 \%$ & $0.02 \%$ \\
\hline Passenger Cars & Gasoline $<0.81$ & PC Euro 3-98/69/EC Stage2000 & $0.14 \%$ & $0.10 \%$ & $0.10 \%$ & $0.10 \%$ & $0.11 \%$ & $0.11 \%$ \\
\hline Passenger Cars & Gasoline $<0.81$ & PC Euro 4-98/69/EC Stage2005 & $0.10 \%$ & $0.07 \%$ & $0.06 \%$ & $0.07 \%$ & $0.07 \%$ & $0.07 \%$ \\
\hline Passenger Cars & Gasoline $<0.81$ & PC Euro 5 - EC 715/2007 & $0.00 \%$ & $0.00 \%$ & $0.00 \%$ & $0.00 \%$ & $0.00 \%$ & $0.00 \%$ \\
\hline Passenger Cars & Gasoline $0.8-1.41$ & PRE ECE & $0.00 \%$ & $0.01 \%$ & $0.01 \%$ & $0.01 \%$ & $0.00 \%$ & $0.00 \%$ \\
\hline Passenger Cars & Gasoline $0.8-1.41$ & ECE 15/00-01 & $0.13 \%$ & $0.64 \%$ & $0.36 \%$ & $0.64 \%$ & $0.23 \%$ & $0.35 \%$ \\
\hline Passenger Cars & Gasoline $0.8-1.41$ & ECE $15 / 02$ & $0.01 \%$ & $0.24 \%$ & $0.03 \%$ & $0.24 \%$ & $0.01 \%$ & $0.08 \%$ \\
\hline Passenger Cars & Gasoline $0.8-1.41$ & ECE $15 / 03$ & $0.02 \%$ & $0.33 \%$ & $0.04 \%$ & $0.33 \%$ & $0.02 \%$ & $0.11 \%$ \\
\hline Passenger Cars & Gasoline $0.8-1.41$ & ECE $15 / 04$ & $0.11 \%$ & $0.46 \%$ & $0.20 \%$ & $0.46 \%$ & $0.20 \%$ & $0.25 \%$ \\
\hline Passenger Cars & Gasoline $0.8-1.41$ & PC Euro 1-91/441/EEC & $0.26 \%$ & $0.46 \%$ & $0.45 \%$ & $0.46 \%$ & $0.46 \%$ & $0.42 \%$ \\
\hline Passenger Cars & Gasoline $0.8-1.41$ & PC Euro 2-94/12/EEC & $0.66 \%$ & $0.86 \%$ & $0.98 \%$ & $0.86 \%$ & $1.03 \%$ & $0.89 \%$ \\
\hline Passenger Cars & Gasoline $0.8-1.41$ & PC Euro 3-98/69/EC Stage2000 & $2.26 \%$ & $2.64 \%$ & $2.82 \%$ & $2.64 \%$ & $2.90 \%$ & $2.68 \%$ \\
\hline Passenger Cars & Gasoline $0.8-1.41$ & PC Euro 4-98/69/EC Stage2005 & $3.66 \%$ & $3.72 \%$ & $3.74 \%$ & $3.72 \%$ & $3.91 \%$ & $3.76 \%$ \\
\hline Passenger Cars & Gasoline $0.8-1.41$ & PC Euro 5 - EC 715/2007 & $1.63 \%$ & $1.53 \%$ & $1.45 \%$ & $1.53 \%$ & $1.45 \%$ & $1.51 \%$ \\
\hline Passenger Cars & Gasoline 1.4-2.01 & PRE ECE & $0.00 \%$ & $0.00 \%$ & $0.00 \%$ & $0.00 \%$ & $0.00 \%$ & $0.00 \%$ \\
\hline Passenger Cars & Gasoline 1.4-2.01 & ECE 15/00-01 & $0.03 \%$ & $0.12 \%$ & $0.07 \%$ & $0.12 \%$ & $0.06 \%$ & $0.07 \%$ \\
\hline Passenger Cars & Gasoline 1.4-2.01 & ECE $15 / 02$ & $0.00 \%$ & $0.08 \%$ & $0.01 \%$ & $0.08 \%$ & $0.00 \%$ & $0.02 \%$ \\
\hline Passenger Cars & Gasoline 1.4-2.01 & ECE $15 / 03$ & $0.01 \%$ & $0.12 \%$ & $0.02 \%$ & $0.12 \%$ & $0.01 \%$ & $0.04 \%$ \\
\hline Passenger Cars & Gasoline 1.4-2.01 & ECE $15 / 04$ & $0.26 \%$ & $0.55 \%$ & $0.39 \%$ & $0.55 \%$ & $0.36 \%$ & $0.40 \%$ \\
\hline Passenger Cars & Gasoline 1.4-2.01 & PC Euro 1-91/441/EEC & $0.66 \%$ & $0.81 \%$ & $0.87 \%$ & $0.81 \%$ & $0.87 \%$ & $0.81 \%$ \\
\hline Passenger Cars & Gasoline 1.4-2.01 & PC Euro 2-94/12/EEC & $1.43 \%$ & $1.58 \%$ & $1.93 \%$ & $1.58 \%$ & $1.84 \%$ & $1.71 \%$ \\
\hline Passenger Cars & Gasoline 1.4-2.01 & PC Euro 3-98/69/EC Stage2000 & $4.04 \%$ & $4.31 \%$ & $4.54 \%$ & $4.31 \%$ & $4.88 \%$ & $4.46 \%$ \\
\hline Passenger Cars & Gasoline 1.4-2.01 & PC Euro 4-98/69/EC Stage2005 & $4.51 \%$ & $4.00 \%$ & $4.01 \%$ & $4.00 \%$ & $4.32 \%$ & $4.19 \%$ \\
\hline Passenger Cars & Gasoline 1.4-2.01 & PC Euro 5 - EC 715/2007 & $1.19 \%$ & $0.95 \%$ & $0.91 \%$ & $0.95 \%$ & $0.91 \%$ & $0.98 \%$ \\
\hline Passenger Cars & Gasoline $>2.01$ & PRE ECE & $0.00 \%$ & $0.00 \%$ & $0.00 \%$ & $0.00 \%$ & $0.00 \%$ & $0.00 \%$ \\
\hline Passenger Cars & Gasoline $>2.01$ & ECE 15/00-01 & $0.00 \%$ & $0.01 \%$ & $0.01 \%$ & $0.01 \%$ & $0.01 \%$ & $0.01 \%$ \\
\hline Passenger Cars & Gasoline $>2.01$ & ECE $15 / 02$ & $0.00 \%$ & $0.00 \%$ & $0.00 \%$ & $0.00 \%$ & $0.00 \%$ & $0.00 \%$ \\
\hline Passenger Cars & Gasoline $>2.01$ & ECE $15 / 03$ & $0.01 \%$ & $0.01 \%$ & $0.00 \%$ & $0.01 \%$ & $0.00 \%$ & $0.01 \%$ \\
\hline
\end{tabular}




\begin{tabular}{|c|c|c|c|c|c|c|c|c|}
\hline Passenger Cars & Gasoline $>2.01$ & ECE $15 / 04$ & $0.03 \%$ & $0.03 \%$ & $0.02 \%$ & $0.03 \%$ & $0.02 \%$ & $0.02 \%$ \\
\hline Passenger Cars & Gasoline $>2.01$ & PC Euro 1-91/441/EEC & $0.31 \%$ & $0.22 \%$ & $0.21 \%$ & $0.22 \%$ & $0.21 \%$ & $0.23 \%$ \\
\hline Passenger Cars & Gasoline $>2.01$ & PC Euro 2-94/12/EEC & $0.46 \%$ & $0.28 \%$ & $0.32 \%$ & $0.28 \%$ & $0.37 \%$ & $0.35 \%$ \\
\hline Passenger Cars & Gasoline $>2.01$ & PC Euro 3-98/69/EC Stage2000 & $1.45 \%$ & $0.82 \%$ & $0.79 \%$ & $0.82 \%$ & $1.01 \%$ & $0.99 \%$ \\
\hline Passenger Cars & Gasoline $>2.01$ & PC Euro 4-98/69/EC Stage2005 & $1.55 \%$ & $0.65 \%$ & $0.64 \%$ & $0.65 \%$ & $0.81 \%$ & $0.87 \%$ \\
\hline Passenger Cars & Gasoline $>2.01$ & PC Euro 5 - EC 715/2007 & $0.24 \%$ & $0.07 \%$ & $0.07 \%$ & $0.07 \%$ & $0.09 \%$ & $0.11 \%$ \\
\hline Passenger Cars & Diesel $<1.41$ & Conventional & $0.00 \%$ & $0.01 \%$ & $0.00 \%$ & $0.01 \%$ & $0.00 \%$ & $0.00 \%$ \\
\hline Passenger Cars & Diesel $<1.41$ & PC Euro 1-91/441/EEC & $0.00 \%$ & $0.01 \%$ & $0.00 \%$ & $0.01 \%$ & $0.00 \%$ & $0.00 \%$ \\
\hline Passenger Cars & Diesel < 1.41 & PC Euro 2-94/12/EEC & $0.01 \%$ & $0.01 \%$ & $0.01 \%$ & $0.01 \%$ & $0.00 \%$ & $0.01 \%$ \\
\hline Passenger Cars & Diesel < 1.41 & PC Euro 3-98/69/EC Stage2000 & $0.57 \%$ & $0.83 \%$ & $0.89 \%$ & $0.83 \%$ & $0.79 \%$ & $0.78 \%$ \\
\hline Passenger Cars & Diesel $<1.41$ & PC Euro 4-98/69/EC Stage2005 & $1.85 \%$ & $2.46 \%$ & $2.48 \%$ & $2.46 \%$ & $2.24 \%$ & $2.28 \%$ \\
\hline Passenger Cars & Diesel $<1.41$ & PC Euro 5 - EC 715/2007 & $0.58 \%$ & $0.80 \%$ & $0.73 \%$ & $0.80 \%$ & $0.77 \%$ & $0.73 \%$ \\
\hline Passenger Cars & Diesel 1.4-2.01 & Conventional & $0.04 \%$ & $0.18 \%$ & $0.06 \%$ & $0.18 \%$ & $0.07 \%$ & $0.09 \%$ \\
\hline Passenger Cars & Diesel 1.4-2.01 & PC Euro 1-91/441/EEC & $0.25 \%$ & $0.53 \%$ & $0.55 \%$ & $0.53 \%$ & $0.53 \%$ & $0.48 \%$ \\
\hline Passenger Cars & Diesel 1.4-2.01 & PC Euro 2-94/12/EEC & $1.53 \%$ & $2.74 \%$ & $3.05 \%$ & $2.74 \%$ & $2.81 \%$ & $2.59 \%$ \\
\hline Passenger Cars & Diesel 1.4-2.01 & PC Euro 3-98/69/EC Stage2000 & $8.31 \%$ & $13.21 \%$ & $13.27 \%$ & $13.21 \%$ & $12.69 \%$ & $12.07 \%$ \\
\hline Passenger Cars & Diesel 1.4-2.01 & PC Euro 4-98/69/EC Stage2005 & $17.96 \%$ & $23.01 \%$ & $21.93 \%$ & $23.01 \%$ & $21.00 \%$ & $21.15 \%$ \\
\hline Passenger Cars & Diesel 1.4-2.01 & PC Euro 5 - EC 715/2007 & $7.17 \%$ & $7.64 \%$ & $6.87 \%$ & $7.64 \%$ & $6.98 \%$ & $7.16 \%$ \\
\hline Passenger Cars & Diesel > 2.01 & Conventional & $0.03 \%$ & $0.10 \%$ & $0.05 \%$ & $0.10 \%$ & $0.04 \%$ & $0.06 \%$ \\
\hline Passenger Cars & Diesel $>2.01$ & PC Euro 1-91/441/EEC & $0.09 \%$ & $0.14 \%$ & $0.13 \%$ & $0.14 \%$ & $0.13 \%$ & $0.13 \%$ \\
\hline Passenger Cars & Diesel > 2.01 & PC Euro 2-94/12/EEC & $0.31 \%$ & $0.36 \%$ & $0.41 \%$ & $0.36 \%$ & $0.43 \%$ & $0.38 \%$ \\
\hline Passenger Cars & Diesel $>2.01$ & PC Euro 3-98/69/EC Stage2000 & $1.88 \%$ & $2.03 \%$ & $1.84 \%$ & $2.03 \%$ & $2.06 \%$ & $1.95 \%$ \\
\hline Passenger Cars & Diesel $>2.01$ & PC Euro 4-98/69/EC Stage2005 & $4.98 \%$ & $3.90 \%$ & $3.53 \%$ & $3.90 \%$ & $4.15 \%$ & $4.08 \%$ \\
\hline Passenger Cars & Diesel $>2.01$ & PC Euro 5 - EC 715/2007 & $1.71 \%$ & $0.99 \%$ & $0.85 \%$ & $0.99 \%$ & $1.15 \%$ & $1.14 \%$ \\
\hline Passenger Cars & LPG & Conventional & $0.00 \%$ & $0.00 \%$ & $0.00 \%$ & $0.00 \%$ & $0.00 \%$ & $0.00 \%$ \\
\hline Passenger Cars & LPG & PC Euro 2-94/12/EEC & $0.00 \%$ & $0.00 \%$ & $0.00 \%$ & $0.00 \%$ & $0.00 \%$ & $0.00 \%$ \\
\hline Passenger Cars & LPG & PC Euro 3-98/69/EC Stage2000 & $0.00 \%$ & $0.00 \%$ & $0.00 \%$ & $0.00 \%$ & $0.01 \%$ & $0.01 \%$ \\
\hline Passenger Cars & LPG & PC Euro 4-98/69/EC Stage2005 & $0.00 \%$ & $0.00 \%$ & $0.00 \%$ & $0.00 \%$ & $0.00 \%$ & $0.00 \%$ \\
\hline Passenger Cars & LPG & PC Euro 5 - EC 715/2007 & $0.00 \%$ & $0.00 \%$ & $0.00 \%$ & $0.00 \%$ & $0.00 \%$ & $0.00 \%$ \\
\hline Passenger Cars & E85 & PC Euro 5 - EC 715/2007 & $0.00 \%$ & $0.00 \%$ & $0.00 \%$ & $0.00 \%$ & $0.00 \%$ & $0.00 \%$ \\
\hline Passenger Cars & CNG & PC Euro 4-98/69/EC Stage2005 & $0.00 \%$ & $0.00 \%$ & $0.00 \%$ & $0.00 \%$ & $0.00 \%$ & $0.00 \%$ \\
\hline Passenger Cars & CNG & PC Euro 5 - EC 715/2007 & $0.00 \%$ & $0.00 \%$ & $0.00 \%$ & $0.00 \%$ & $0.00 \%$ & $0.00 \%$ \\
\hline Passenger Cars & Hybrid Gasoline $<1.41$ & PC Euro 4-98/69/EC Stage2005 & $0.01 \%$ & $0.01 \%$ & $0.01 \%$ & $0.01 \%$ & $0.00 \%$ & $0.01 \%$ \\
\hline Passenger Cars & Hybrid Gasoline 1.4-2.01 & PC Euro 4-98/69/EC Stage2005 & $0.02 \%$ & $0.02 \%$ & $0.02 \%$ & $0.02 \%$ & $0.01 \%$ & $0.02 \%$ \\
\hline Passenger Cars & Hybrid Gasoline $>2.01$ & PC Euro 4-98/69/EC Stage2005 & $0.01 \%$ & $0.00 \%$ & $0.00 \%$ & $0.00 \%$ & $0.00 \%$ & $0.00 \%$ \\
\hline Light Commercial Vehicles & Gasoline $<3.5 t$ & Conventional & $0.02 \%$ & $0.18 \%$ & $0.06 \%$ & $0.18 \%$ & $0.04 \%$ & $0.08 \%$ \\
\hline Light Commercial Vehicles & Gasoline $<3.5 t$ & LD Euro 1-93/59/EEC & $0.01 \%$ & $0.01 \%$ & $0.01 \%$ & $0.01 \%$ & $0.02 \%$ & $0.01 \%$ \\
\hline Light Commercial Vehicles & Gasoline $<3.5 \mathrm{t}$ & LD Euro 2-96/69/EEC & $0.01 \%$ & $0.01 \%$ & $0.01 \%$ & $0.01 \%$ & $0.01 \%$ & $0.01 \%$ \\
\hline Light Commercial Vehicles & Gasoline $<3.5 \mathrm{t}$ & LD Euro 3-98/69/EC Stage2000 & $0.05 \%$ & $0.06 \%$ & $0.07 \%$ & $0.06 \%$ & $0.08 \%$ & $0.07 \%$ \\
\hline Light Commercial Vehicles & Gasoline $<3.5 \mathrm{t}$ & LD Euro 4-98/69/EC Stage2005 & $0.05 \%$ & $0.06 \%$ & $0.07 \%$ & $0.06 \%$ & $0.06 \%$ & $0.06 \%$ \\
\hline Light Commercial Vehicles & Gasoline $<3.5 \mathrm{t}$ & LD Euro 5-2008 Standards & $0.01 \%$ & $0.01 \%$ & $0.00 \%$ & $0.01 \%$ & $0.01 \%$ & $0.01 \%$ \\
\hline Light Commercial Vehicles & Diesel $<3.5 t$ & Conventional & $0.03 \%$ & $0.23 \%$ & $0.08 \%$ & $0.23 \%$ & $0.07 \%$ & $0.11 \%$ \\
\hline Light Commercial Vehicles & Diesel $<3.5 \mathrm{t}$ & LD Euro 1-93/59/EEC & $0.05 \%$ & $0.14 \%$ & $0.14 \%$ & $0.14 \%$ & $0.13 \%$ & $0.12 \%$ \\
\hline Light Commercial Vehicles & Diesel $<3.5 t$ & LD Euro 2-96/69/EEC & $0.18 \%$ & $0.38 \%$ & $0.45 \%$ & $0.38 \%$ & $0.45 \%$ & $0.37 \%$ \\
\hline Light Commercial Vehicles & Diesel $<3.5 t$ & LD Euro 3-98/69/EC Stage2000 & $1.06 \%$ & $2.05 \%$ & $2.24 \%$ & $2.05 \%$ & $2.20 \%$ & $1.93 \%$ \\
\hline Light Commercial Vehicles & Diesel $<3.5 t$ & LD Euro 4-98/69/EC Stage2005 & $2.53 \%$ & $4.14 \%$ & $4.31 \%$ & $4.14 \%$ & $4.15 \%$ & $3.85 \%$ \\
\hline Light Commercial Vehicles & Diesel $<3.5 t$ & LD Euro 5-2008 Standards & $0.74 \%$ & $1.22 \%$ & $1.19 \%$ & $1.22 \%$ & $1.19 \%$ & $1.10 \%$ \\
\hline Heavy Duty Vehicles & Gasoline $>3.5 \mathrm{t}$ & Conventional & $0.01 \%$ & $0.01 \%$ & $0.01 \%$ & $0.01 \%$ & $0.01 \%$ & $0.01 \%$ \\
\hline Heavy Duty Vehicles & Rigid $\leq 7.5 \mathrm{t}$ & Conventional & $0.01 \%$ & $0.06 \%$ & $0.02 \%$ & $0.06 \%$ & $0.01 \%$ & $0.03 \%$ \\
\hline Heavy Duty Vehicles & Rigid $\leq 7.5 \mathrm{t}$ & HD Euro I - 91/542/EEC Stage I & $0.00 \%$ & $0.02 \%$ & $0.01 \%$ & $0.02 \%$ & $0.01 \%$ & $0.01 \%$ \\
\hline Heavy Duty Vehicles & Rigid $\leq 7.5 \mathrm{t}$ & HD Euro II - 91/542/EEC Stage II & $0.03 \%$ & $0.10 \%$ & $0.08 \%$ & $0.10 \%$ & $0.10 \%$ & $0.08 \%$ \\
\hline Heavy Duty Vehicles & Rigid $\leq 7.5 \mathrm{t}$ & HD Euro III - 2000 Standards & $0.19 \%$ & $0.46 \%$ & $0.41 \%$ & $0.46 \%$ & $0.38 \%$ & $0.37 \%$ \\
\hline Heavy Duty Vehicles & Rigid $\leq 7.5 \mathrm{t}$ & HD Euro IV - 2005 Standards & $0.24 \%$ & $0.48 \%$ & $0.46 \%$ & $0.48 \%$ & $0.46 \%$ & $0.42 \%$ \\
\hline Heavy Duty Vehicles & Rigid $\leq 7.5 \mathrm{t}$ & HD Euro V - 2008 Standards & $0.31 \%$ & $0.57 \%$ & $0.48 \%$ & $0.57 \%$ & $0.57 \%$ & $0.49 \%$ \\
\hline Heavy Duty Vehicles & Rigid 7.5-12t & Conventional & $0.00 \%$ & $0.01 \%$ & $0.01 \%$ & $0.01 \%$ & $0.01 \%$ & $0.01 \%$ \\
\hline Heavy Duty Vehicles & Rigid 7.5-12t & HD Euro I - 91/542/EEC Stage I & $0.00 \%$ & $0.00 \%$ & $0.00 \%$ & $0.00 \%$ & $0.00 \%$ & $0.00 \%$ \\
\hline Heavy Duty Vehicles & Rigid 7.5-12t & HD Euro II - 91/542/EEC Stage II & $0.00 \%$ & $0.01 \%$ & $0.01 \%$ & $0.01 \%$ & $0.01 \%$ & $0.01 \%$ \\
\hline Heavy Duty Vehicles & Rigid $7.5-12 \mathrm{t}$ & HD Euro III - 2000 Standards & $0.01 \%$ & $0.03 \%$ & $0.04 \%$ & $0.03 \%$ & $0.03 \%$ & $0.03 \%$ \\
\hline Heavy Duty Vehicles & Rigid $7.5-12 \mathrm{t}$ & HD Euro IV - 2005 Standards & $0.01 \%$ & $0.02 \%$ & $0.02 \%$ & $0.02 \%$ & $0.03 \%$ & $0.02 \%$ \\
\hline Heavy Duty Vehicles & Rigid $7.5-12 \mathrm{t}$ & HD Euro V - 2008 Standards & $0.02 \%$ & $0.03 \%$ & $0.04 \%$ & $0.03 \%$ & $0.04 \%$ & $0.03 \%$ \\
\hline Heavy Duty Vehicles & Rigid $12-14$ t & Conventional & $0.00 \%$ & $0.00 \%$ & $0.00 \%$ & $0.00 \%$ & $0.00 \%$ & $0.00 \%$ \\
\hline Heavy Duty Vehicles & Rigid $12-14 \mathrm{t}$ & HD Euro I - 91/542/EEC Stage I & $0.00 \%$ & $0.00 \%$ & $0.00 \%$ & $0.00 \%$ & $0.00 \%$ & $0.00 \%$ \\
\hline Heavy Duty Vehicles & Rigid $12-14 \mathrm{t}$ & HD Euro II - 91/542/EEC Stage II & $0.00 \%$ & $0.00 \%$ & $0.00 \%$ & $0.00 \%$ & $0.00 \%$ & $0.00 \%$ \\
\hline Heavy Duty Vehicles & Rigid $12-14$ t & HD Euro III - 2000 Standards & $0.00 \%$ & $0.00 \%$ & $0.00 \%$ & $0.00 \%$ & $0.00 \%$ & $0.00 \%$ \\
\hline Heavy Duty Vehicles & Rigid $12-14$ t & HD Euro IV - 2005 Standards & $0.00 \%$ & $0.00 \%$ & $0.00 \%$ & $0.00 \%$ & $0.00 \%$ & $0.00 \%$ \\
\hline Heavy Duty Vehicles & Rigid $12-14 \mathrm{t}$ & HD Euro V - 2008 Standards & $0.00 \%$ & $0.00 \%$ & $0.00 \%$ & $0.00 \%$ & $0.00 \%$ & $0.00 \%$ \\
\hline Heavy Duty Vehicles & Rigid 14-20 t & Conventional & $0.00 \%$ & $0.02 \%$ & $0.01 \%$ & $0.02 \%$ & $0.01 \%$ & $0.01 \%$ \\
\hline Heavy Duty Vehicles & Rigid $14-20 t$ & HD Euro I - 91/542/EEC Stage I & $0.00 \%$ & $0.00 \%$ & $0.00 \%$ & $0.00 \%$ & $0.00 \%$ & $0.00 \%$ \\
\hline Heavy Duty Vehicles & Rigid $14-20 t$ & HD Euro II - 91/542/EEC Stage II & $0.00 \%$ & $0.01 \%$ & $0.01 \%$ & $0.01 \%$ & $0.02 \%$ & $0.01 \%$ \\
\hline Heavy Duty Vehicles & Rigid $14-20 t$ & HD Euro III - 2000 Standards & $0.02 \%$ & $0.03 \%$ & $0.03 \%$ & $0.03 \%$ & $0.04 \%$ & $0.03 \%$ \\
\hline Heavy Duty Vehicles & Rigid 14-20 t & HD Euro IV - 2005 Standards & $0.02 \%$ & $0.03 \%$ & $0.02 \%$ & $0.03 \%$ & $0.04 \%$ & $0.03 \%$ \\
\hline Heavy Duty Vehicles & Rigid $14-20 t$ & HD Euro V - 2008 Standards & $0.02 \%$ & $0.03 \%$ & $0.02 \%$ & $0.03 \%$ & $0.04 \%$ & $0.03 \%$ \\
\hline Heavy Duty Vehicles & Rigid $20-26 t$ & Conventional & $0.00 \%$ & $0.01 \%$ & $0.00 \%$ & $0.01 \%$ & $0.01 \%$ & $0.01 \%$ \\
\hline Heavy Duty Vehicles & Rigid $20-26 t$ & HD Euro I - 91/542/EEC Stage I & $0.00 \%$ & $0.00 \%$ & $0.00 \%$ & $0.00 \%$ & $0.00 \%$ & $0.00 \%$ \\
\hline Heavy Duty Vehicles & Rigid $20-26 \mathrm{t}$ & HD Euro II - 91/542/EEC Stage II & $0.00 \%$ & $0.00 \%$ & $0.00 \%$ & $0.00 \%$ & $0.00 \%$ & $0.00 \%$ \\
\hline Heavy Duty Vehicles & Rigid $20-26 \mathrm{t}$ & HD Euro III - 2000 Standards & $0.01 \%$ & $0.01 \%$ & $0.01 \%$ & $0.01 \%$ & $0.02 \%$ & $0.01 \%$ \\
\hline Heavy Duty Vehicles & Rigid $20-26 t$ & HD Euro IV - 2005 Standards & $0.01 \%$ & $0.01 \%$ & $0.01 \%$ & $0.01 \%$ & $0.01 \%$ & $0.01 \%$ \\
\hline Heavy Duty Vehicles & Rigid 20-26t & HD Euro V - 2008 Standards & $0.01 \%$ & $0.00 \%$ & $0.01 \%$ & $0.00 \%$ & $0.01 \%$ & $0.01 \%$ \\
\hline Heavy Duty Vehicles & Rigid 26-28 t & Conventional & $0.00 \%$ & $0.00 \%$ & $0.00 \%$ & $0.00 \%$ & $0.00 \%$ & $0.00 \%$ \\
\hline Heavy Duty Vehicles & Rigid 26-28t & HD Euro II - 91/542/EEC Stage II & $0.00 \%$ & $0.00 \%$ & $0.00 \%$ & $0.00 \%$ & $0.00 \%$ & $0.00 \%$ \\
\hline
\end{tabular}




\begin{tabular}{|c|c|c|c|c|c|c|c|c|}
\hline Heavy Duty Vehicles & Rigid $26-28 t$ & HD Euro III - 2000 Standards & $0.00 \%$ & $0.00 \%$ & $0.00 \%$ & $0.00 \%$ & $0.00 \%$ & $0.00 \%$ \\
\hline Heavy Duty Vehicles & Rigid $26-28 \mathrm{t}$ & HD Euro IV - 2005 Standards & $0.00 \%$ & $0.00 \%$ & $0.00 \%$ & $0.00 \%$ & $0.00 \%$ & $0.00 \%$ \\
\hline Heavy Duty Vehicles & Rigid 26-28t & HD Euro V - 2008 Standards & $0.00 \%$ & $0.00 \%$ & $0.00 \%$ & $0.00 \%$ & $0.00 \%$ & $0.00 \%$ \\
\hline Heavy Duty Vehicles & Rigid 28-32t & Conventional & $0.00 \%$ & $0.00 \%$ & $0.00 \%$ & $0.00 \%$ & $0.00 \%$ & $0.00 \%$ \\
\hline Heavy Duty Vehicles & Rigid 28-32t & HD Euro I - 91/542/EEC Stage I & $0.00 \%$ & $0.00 \%$ & $0.00 \%$ & $0.00 \%$ & $0.00 \%$ & $0.00 \%$ \\
\hline Heavy Duty Vehicles & Rigid 28-32t & HD Euro II - 91/542/EEC Stage II & $0.00 \%$ & $0.00 \%$ & $0.00 \%$ & $0.00 \%$ & $0.00 \%$ & $0.00 \%$ \\
\hline Heavy Duty Vehicles & Rigid $28-32 \mathrm{t}$ & HD Euro III - 2000 Standards & $0.00 \%$ & $0.00 \%$ & $0.00 \%$ & $0.00 \%$ & $0.00 \%$ & $0.00 \%$ \\
\hline Heavy Duty Vehicles & Rigid 28-32t & HD Euro IV - 2005 Standards & $0.00 \%$ & $0.00 \%$ & $0.00 \%$ & $0.00 \%$ & $0.00 \%$ & $0.00 \%$ \\
\hline Heavy Duty Vehicles & Rigid 28-32t & HD Euro V - 2008 Standards & $0.00 \%$ & $0.00 \%$ & $0.00 \%$ & $0.00 \%$ & $0.00 \%$ & $0.00 \%$ \\
\hline Heavy Duty Vehicles & Rigid $>32 t$ & Conventional & $0.00 \%$ & $0.02 \%$ & $0.00 \%$ & $0.02 \%$ & $0.01 \%$ & $0.01 \%$ \\
\hline Heavy Duty Vehicles & Rigid $>32 t$ & HD Euro I - 91/542/EEC Stage I & $0.00 \%$ & $0.00 \%$ & $0.00 \%$ & $0.00 \%$ & $0.00 \%$ & $0.00 \%$ \\
\hline Heavy Duty Vehicles & Rigid $>32 t$ & HD Euro II - 91/542/EEC Stage II & $0.00 \%$ & $0.00 \%$ & $0.00 \%$ & $0.00 \%$ & $0.00 \%$ & $0.00 \%$ \\
\hline Heavy Duty Vehicles & Rigid $>32 t$ & HD Euro III - 2000 Standards & $0.00 \%$ & $0.00 \%$ & $0.00 \%$ & $0.00 \%$ & $0.00 \%$ & $0.00 \%$ \\
\hline Heavy Duty Vehicles & Rigid $>32 \mathrm{t}$ & HD Euro IV - 2005 Standards & $0.00 \%$ & $0.00 \%$ & $0.00 \%$ & $0.00 \%$ & $0.00 \%$ & $0.00 \%$ \\
\hline Heavy Duty Vehicles & Rigid $>32 t$ & HD Euro V - 2008 Standards & $0.00 \%$ & $0.00 \%$ & $0.00 \%$ & $0.00 \%$ & $0.00 \%$ & $0.00 \%$ \\
\hline Heavy Duty Vehicles Articulated & Articulated $14-20 \mathrm{t}$ & Conventional & $0.00 \%$ & $0.00 \%$ & $0.00 \%$ & $0.00 \%$ & $0.00 \%$ & $0.00 \%$ \\
\hline Heavy Duty Vehicles Articulated & Articulated $14-20 \mathrm{t}$ & HD Euro I - 91/542/EEC Stage I & $0.00 \%$ & $0.00 \%$ & $0.00 \%$ & $0.00 \%$ & $0.00 \%$ & $0.00 \%$ \\
\hline Heavy Duty Vehicles Articulated & Articulated $14-20 \mathrm{t}$ & HD Euro II - 91/542/EEC Stage II & $0.00 \%$ & $0.00 \%$ & $0.00 \%$ & $0.00 \%$ & $0.00 \%$ & $0.00 \%$ \\
\hline Heavy Duty Vehicles Articulated & Articulated $14-20 \mathrm{t}$ & HD Euro III - 2000 Standards & $0.00 \%$ & $0.00 \%$ & $0.00 \%$ & $0.00 \%$ & $0.00 \%$ & $0.00 \%$ \\
\hline Heavy Duty Vehicles Articulated & Articulated $14-20 \mathrm{t}$ & HD Euro IV - 2005 Standards & $0.00 \%$ & $0.01 \%$ & $0.01 \%$ & $0.01 \%$ & $0.01 \%$ & $0.01 \%$ \\
\hline Heavy Duty Vehicles Articulated & Articulated $14-20 t$ & HD Euro V - 2008 Standards & $0.00 \%$ & $0.01 \%$ & $0.00 \%$ & $0.01 \%$ & $0.00 \%$ & $0.00 \%$ \\
\hline Heavy Duty Vehicles Articulated & Articulated $20-28 \mathrm{t}$ & Conventional & $0.00 \%$ & $0.00 \%$ & $0.00 \%$ & $0.00 \%$ & $0.00 \%$ & $0.00 \%$ \\
\hline Heavy Duty Vehicles Articulated & Articulated $20-28 \mathrm{t}$ & HD Euro I - 91/542/EEC Stage I & $0.00 \%$ & $0.00 \%$ & $0.00 \%$ & $0.00 \%$ & $0.00 \%$ & $0.00 \%$ \\
\hline Heavy Duty Vehicles Articulated & Articulated $20-28 \mathrm{t}$ & HD Euro II - 91/542/EEC Stage II & $0.00 \%$ & $0.00 \%$ & $0.00 \%$ & $0.00 \%$ & $0.00 \%$ & $0.00 \%$ \\
\hline Heavy Duty Vehicles Articulated & Articulated $20-28 \mathrm{t}$ & HD Euro III - 2000 Standards & $0.00 \%$ & $0.00 \%$ & $0.00 \%$ & $0.00 \%$ & $0.00 \%$ & $0.00 \%$ \\
\hline Heavy Duty Vehicles Articulated & Articulated $20-28 \mathrm{t}$ & HD Euro IV - 2005 Standards & $0.00 \%$ & $0.00 \%$ & $0.00 \%$ & $0.00 \%$ & $0.00 \%$ & $0.00 \%$ \\
\hline Heavy Duty Vehicles Articulated & Articulated $20-28 \mathrm{t}$ & HD Euro V - 2008 Standards & $0.00 \%$ & $0.00 \%$ & $0.00 \%$ & $0.00 \%$ & $0.00 \%$ & $0.00 \%$ \\
\hline Heavy Duty Vehicles Articulated & Articulated $28-34 \mathrm{t}$ & HD Euro I - 91/542/EEC Stage I & $0.00 \%$ & $0.00 \%$ & $0.00 \%$ & $0.00 \%$ & $0.00 \%$ & $0.00 \%$ \\
\hline Heavy Duty Vehicles Articulated & Articulated $28-34 \mathrm{t}$ & HD Euro III - 2000 Standards & $0.00 \%$ & $0.00 \%$ & $0.00 \%$ & $0.00 \%$ & $0.00 \%$ & $0.00 \%$ \\
\hline Heavy Duty Vehicles Articulated & Articulated $28-34 \mathrm{t}$ & HD Euro IV - 2005 Standards & $0.00 \%$ & $0.00 \%$ & $0.00 \%$ & $0.00 \%$ & $0.00 \%$ & $0.00 \%$ \\
\hline Heavy Duty Vehicles Articulated & Articulated $28-34 \mathrm{t}$ & HD Euro V - 2008 Standards & $0.00 \%$ & $0.00 \%$ & $0.00 \%$ & $0.00 \%$ & $0.00 \%$ & $0.00 \%$ \\
\hline Heavy Duty Vehicles Articulated & Articulated $34-40 \mathrm{t}$ & Conventional & $0.00 \%$ & $0.00 \%$ & $0.00 \%$ & $0.00 \%$ & $0.00 \%$ & $0.00 \%$ \\
\hline Buses & Urban Buses Midi $\leq 15 \mathrm{t}$ & Conventional & $0.00 \%$ & $0.00 \%$ & $0.00 \%$ & $0.00 \%$ & $0.00 \%$ & $0.00 \%$ \\
\hline Buses & Urban Buses Midi $\leq 15 \mathrm{t}$ & HD Euro I - 91/542/EEC Stage I & $0.00 \%$ & $0.00 \%$ & $0.00 \%$ & $0.00 \%$ & $0.00 \%$ & $0.00 \%$ \\
\hline Buses & Urban Buses Midi $\leq 15 \mathrm{t}$ & HD Euro II - 91/542/EEC Stage II & $0.01 \%$ & $0.01 \%$ & $0.02 \%$ & $0.01 \%$ & $0.02 \%$ & $0.01 \%$ \\
\hline Buses & Urban Buses Midi $\leq 15 \mathrm{t}$ & HD Euro III - 2000 Standards & $0.02 \%$ & $0.03 \%$ & $0.04 \%$ & $0.03 \%$ & $0.05 \%$ & $0.03 \%$ \\
\hline Buses & Urban Buses Midi $\leq 15 t$ & HD Euro IV - 2005 Standards & $0.02 \%$ & $0.03 \%$ & $0.04 \%$ & $0.03 \%$ & $0.03 \%$ & $0.03 \%$ \\
\hline Buses & Urban Buses Midi $\leq 15 \mathrm{t}$ & HD Euro V - 2008 Standards & $0.03 \%$ & $0.07 \%$ & $0.06 \%$ & $0.07 \%$ & $0.06 \%$ & $0.06 \%$ \\
\hline Buses & Urban Buses Standard 15-18t & Conventional & $0.00 \%$ & $0.00 \%$ & $0.00 \%$ & $0.00 \%$ & $0.00 \%$ & $0.00 \%$ \\
\hline Buses & Urban Buses Standard 15-18t & HD Euro I - 91/542/EEC Stage I & $0.00 \%$ & $0.00 \%$ & $0.00 \%$ & $0.00 \%$ & $0.00 \%$ & $0.00 \%$ \\
\hline Buses & Urban Buses Standard 15-18t & HD Euro II - 91/542/EEC Stage II & $0.01 \%$ & $0.02 \%$ & $0.01 \%$ & $0.02 \%$ & $0.01 \%$ & $0.01 \%$ \\
\hline Buses & Urban Buses Standard 15-18t & HD Euro III - 2000 Standards & $0.03 \%$ & $0.06 \%$ & $0.06 \%$ & $0.06 \%$ & $0.12 \%$ & $0.07 \%$ \\
\hline Buses & Urban Buses Standard 15-18t & HD Euro IV - 2005 Standards & $0.03 \%$ & $0.09 \%$ & $0.06 \%$ & $0.09 \%$ & $0.14 \%$ & $0.08 \%$ \\
\hline Buses & Urban Buses Standard 15-18t & HD Euro V - 2008 Standards & $0.02 \%$ & $0.19 \%$ & $0.03 \%$ & $0.19 \%$ & $0.07 \%$ & $0.08 \%$ \\
\hline Buses & Urban Buses Articulated $>18 t$ & Conventional & $0.00 \%$ & $0.00 \%$ & $0.00 \%$ & $0.00 \%$ & $0.00 \%$ & $0.00 \%$ \\
\hline Buses & Urban Buses Articulated $>18 t$ & HD Euro I - 91/542/EEC Stage I & $0.00 \%$ & $0.00 \%$ & $0.00 \%$ & $0.00 \%$ & $0.00 \%$ & $0.00 \%$ \\
\hline Buses & Urban Buses Articulated $>18 \mathrm{t}$ & HD Euro II - 91/542/EEC Stage II & $0.00 \%$ & $0.00 \%$ & $0.01 \%$ & $0.00 \%$ & $0.00 \%$ & $0.00 \%$ \\
\hline Buses & Urban Buses Articulated $>18 \mathrm{t}$ & HD Euro III - 2000 Standards & $0.43 \%$ & $0.08 \%$ & $0.40 \%$ & $0.08 \%$ & $0.46 \%$ & $0.34 \%$ \\
\hline Buses & Urban Buses Articulated $>18 \mathrm{t}$ & HD Euro IV - 2005 Standards & $0.23 \%$ & $0.09 \%$ & $0.32 \%$ & $0.09 \%$ & $0.28 \%$ & $0.23 \%$ \\
\hline Buses & Urban Buses Articulated $>18 \mathrm{t}$ & HD Euro V - 2008 Standards & $0.32 \%$ & $0.28 \%$ & $0.26 \%$ & $0.28 \%$ & $1.73 \%$ & $0.64 \%$ \\
\hline Coaches & Coaches Standard $\leq 18 \mathrm{t}$ & HD Euro IV - 2005 Standards & $0.00 \%$ & $0.00 \%$ & $0.00 \%$ & $0.00 \%$ & $0.00 \%$ & $0.00 \%$ \\
\hline Coaches & Coaches Standard $\leq 18 \mathrm{t}$ & HD Euro V - 2008 Standards & $0.00 \%$ & $0.00 \%$ & $0.00 \%$ & $0.00 \%$ & $0.00 \%$ & $0.00 \%$ \\
\hline Coaches & Coaches Articulated $>18 \mathrm{t}$ & HD Euro III - 2000 Standards & $0.00 \%$ & $0.00 \%$ & $0.00 \%$ & $0.00 \%$ & $0.00 \%$ & $0.00 \%$ \\
\hline Coaches & Coaches Articulated $>18 \mathrm{t}$ & HD Euro IV - 2005 Standards & $0.00 \%$ & $0.00 \%$ & $0.00 \%$ & $0.00 \%$ & $0.00 \%$ & $0.00 \%$ \\
\hline Buses & Urban CNG Buses & EEV & $0.82 \%$ & $0.01 \%$ & $0.33 \%$ & $0.01 \%$ & $0.14 \%$ & $0.30 \%$ \\
\hline Motorcycles & 4-stroke $<250 \mathrm{~cm}^{3}$ & Conventional & $0.10 \%$ & $0.10 \%$ & $0.03 \%$ & $0.10 \%$ & $0.03 \%$ & $0.06 \%$ \\
\hline Motorcycles & 4-stroke $<250 \mathrm{~cm}^{3}$ & Mot - Euro I & $0.20 \%$ & $0.02 \%$ & $0.03 \%$ & $0.02 \%$ & $0.04 \%$ & $0.06 \%$ \\
\hline Motorcycles & 4-stroke $<250 \mathrm{~cm}^{3}$ & Mot - Euro II & $0.65 \%$ & $0.04 \%$ & $0.09 \%$ & $0.04 \%$ & $0.14 \%$ & $0.21 \%$ \\
\hline Motorcycles & 4-stroke $<250 \mathrm{~cm}^{3}$ & Mot - Euro III & $3.61 \%$ & $0.16 \%$ & $0.42 \%$ & $0.16 \%$ & $0.63 \%$ & $1.08 \%$ \\
\hline Motorcycles & 4-stroke $250-750 \mathrm{~cm}^{3}$ & Conventional & $0.09 \%$ & $0.04 \%$ & $0.02 \%$ & $0.04 \%$ & $0.02 \%$ & $0.04 \%$ \\
\hline Motorcycles & 4-stroke $250-750 \mathrm{~cm}^{3}$ & Mot - Euro I & $0.13 \%$ & $0.01 \%$ & $0.02 \%$ & $0.01 \%$ & $0.02 \%$ & $0.04 \%$ \\
\hline Motorcycles & 4-stroke $250-750 \mathrm{~cm}^{3}$ & Mot - Euro II & $0.33 \%$ & $0.02 \%$ & $0.06 \%$ & $0.02 \%$ & $0.07 \%$ & $0.11 \%$ \\
\hline Motorcycles & 4-stroke $250-750 \mathrm{~cm}^{3}$ & Mot - Euro III & $1.97 \%$ & $0.07 \%$ & $0.31 \%$ & $0.07 \%$ & $0.35 \%$ & $0.61 \%$ \\
\hline Motorcycles & 4-stroke $>750 \mathrm{~cm}^{3}$ & Conventional & $0.03 \%$ & $0.01 \%$ & $0.01 \%$ & $0.01 \%$ & $0.01 \%$ & $0.01 \%$ \\
\hline Motorcycles & 4-stroke $>750 \mathrm{~cm}^{3}$ & Mot - Euro I & $0.05 \%$ & $0.01 \%$ & $0.01 \%$ & $0.01 \%$ & $0.02 \%$ & $0.02 \%$ \\
\hline Motorcycles & 4-stroke $>750 \mathrm{~cm}^{3}$ & Mot - Euro II & $0.11 \%$ & $0.01 \%$ & $0.01 \%$ & $0.01 \%$ & $0.01 \%$ & $0.03 \%$ \\
\hline Motorcycles & 4-stroke $>750 \mathrm{~cm}^{3}$ & Mot - Euro III & $1.04 \%$ & $0.03 \%$ & $0.14 \%$ & $0.03 \%$ & $0.18 \%$ & $0.31 \%$ \\
\hline Passenger Cars & Electric & Electric & $0.02 \%$ & $0.01 \%$ & $0.00 \%$ & $0.01 \%$ & $0.01 \%$ & $0.01 \%$ \\
\hline Passenger Cars & Solar & Solar & $0.00 \%$ & $0.00 \%$ & $0.00 \%$ & $0.00 \%$ & $0.00 \%$ & $0.00 \%$ \\
\hline Light Commercial Vehicles & Electric & Electric & $0.00 \%$ & $0.00 \%$ & $0.00 \%$ & $0.00 \%$ & $0.00 \%$ & $0.00 \%$ \\
\hline Motorcycles & Electric & Electric & $0.01 \%$ & $0.00 \%$ & $0.00 \%$ & $0.00 \%$ & $0.00 \%$ & $0.00 \%$ \\
\hline Buses & Electric & Electric & $0.00 \%$ & $0.00 \%$ & $0.01 \%$ & $0.00 \%$ & $0.00 \%$ & $0.00 \%$ \\
\hline Taxis & Diesel $<1.41$ & PC Euro 4-98/69/EC Stage2005 & $0.00 \%$ & $0.00 \%$ & $0.00 \%$ & $0.00 \%$ & $0.00 \%$ & $0.00 \%$ \\
\hline Taxis & Diesel $<1.41$ & PC Euro 5 - EC 715/2007 & $0.00 \%$ & $0.00 \%$ & $0.00 \%$ & $0.00 \%$ & $0.00 \%$ & $0.00 \%$ \\
\hline Taxis & Diesel 1.4-2.01 & PC Euro 3-98/69/EC Stage2000 & $0.82 \%$ & $0.22 \%$ & $0.32 \%$ & $0.22 \%$ & $0.22 \%$ & $0.38 \%$ \\
\hline Taxis & Diesel 1.4-2.01 & PC Euro 4-98/69/EC Stage2005 & $5.96 \%$ & $1.62 \%$ & $2.36 \%$ & $1.62 \%$ & $1.47 \%$ & $2.71 \%$ \\
\hline Taxis & Diesel 1.4-2.01 & PC Euro 5 - EC 715/2007 & $1.53 \%$ & $0.57 \%$ & $0.64 \%$ & $0.57 \%$ & $0.44 \%$ & $0.76 \%$ \\
\hline Taxis & Diesel > 2.01 & PC Euro 3-98/69/EC Stage2000 & $0.01 \%$ & $0.00 \%$ & $0.00 \%$ & $0.00 \%$ & $0.01 \%$ & $0.01 \%$ \\
\hline Taxis & Diesel $>2.01$ & PC Euro 4-98/69/EC Stage2005 & $0.12 \%$ & $0.04 \%$ & $0.04 \%$ & $0.04 \%$ & $0.06 \%$ & $0.06 \%$ \\
\hline Taxis & Diesel $>2.01$ & PC Euro 5 - EC 715/2007 & $0.04 \%$ & $0.01 \%$ & $0.01 \%$ & $0.01 \%$ & $0.02 \%$ & $0.02 \%$ \\
\hline
\end{tabular}




\begin{tabular}{|c|c|c|c|c|c|c|c|c|}
\hline Taxis & LPG & PC Euro 4-98/69/EC Stage2005 & $0.35 \%$ & $0.13 \%$ & $0.13 \%$ & $0.13 \%$ & $0.06 \%$ & $0.16 \%$ \\
\hline Taxis & LPG & PC Euro 5 - EC 715/2007 & $0.34 \%$ & $0.13 \%$ & $0.13 \%$ & $0.13 \%$ & $0.08 \%$ & $0.16 \%$ \\
\hline Taxis & CNG & PC Euro 4-98/69/EC Stage2005 & $0.00 \%$ & $0.00 \%$ & $0.00 \%$ & $0.00 \%$ & $0.00 \%$ & $0.00 \%$ \\
\hline Taxis & Hybrid Gasoline 1.4-2.0 1 & PC Euro 4-98/69/EC Stage2005 & $1.76 \%$ & $0.48 \%$ & $0.69 \%$ & $0.48 \%$ & $0.42 \%$ & $0.80 \%$ \\
\hline Mopeds & Gasoline & & $0.52 \%$ & $0.00 \%$ & $0.67 \%$ & $0.00 \%$ & $0.20 \%$ & $0.35 \%$ \\
\hline TOTAL & & & $100.00 \%$ & $100.00 \%$ & $100.00 \%$ & $100.00 \%$ & $100.00 \%$ & $100.00 \%$ \\
\hline
\end{tabular}

\section{References}

Alam, A., Hatzopoulou, M., 2014. Investigating the isolated and combined effects of congestion, roadway grade, passenger load, and alternative fuels on transit bus emissions. Transport. Res. Transport Environ. 29, 12-21. https://doi.org/10.1016/j. trd.2014.03.005.

Alvarez, R., Weilenmann, M., Favez, J.Y., 2008. Evidence of increased mass fraction of $\mathrm{NO}_{2}$ within real-world NOx emissions of modern light vehicles - derived from a reliable online measuring method. Atmos. Environ. 42, 4699-4707. https://doi.org/ 10.1016/j.atmosenv.2008.01.046.

Ayuntamiento de Madrid, AM, 2012a. Plan de calidad del aire de la ciudad de Madrid 2011-2015. April 2012. http://www.madrid.es/UnidadesDescentralizadas/ Sostenibilidad/ContenidosBasicos/Ficheros/PlanCalidadAire2012.pdf.

Ayuntamiento de Madrid, AM, 2012b. Ordenanza Reguladora del Taxi. Approved by the governing board of Madrid City Council on November 28, 2012. https://sede. madrid.es/sites/v/index.jsp?vgnextoid = 49778f9c578ab310VgnVCM1000000b205a0aRCRD\&vgnextchannel = 6b3d814231ede410VgnVCM1000000b205a0aRCRD.

Ayuntamiento de Madrid, AM, 2014. Plan de Uso Sostenible de la Energía y Prevención del Cambio Climático-Horizonte 2020. May 2014. http://www.madrid.es/ UnidadesDescentralizadas/Sostenibilidad/EspeInf/EnergiayCC/02PECCH/Ficheros/ PECCH2020.pdf.

Ayuntamiento de Madrid, AM, 2015. Air Pollutant Emissions Inventory of the Municipality of Madrid 2013. Directorate General for Sustainability and Environmental Control. Madrid City Council, 2015. http://www.mambiente. munimadrid.es/opencms/export/sites/default/calaire/Anexos/EmissionsInEm2013. pdf.

Ayuntamiento de Madrid, AM, 2016. Madrid 2015 annual air quality assessment report (Calidad del aire Madrid 2015). General Directorate of Sustainability and Environmental Control, Madrid City Council 2016 Available online -only Spanish version- at. http://www.mambiente.munimadrid.es/opencms/export/sites/default/ calaire/Anexos/Memoria2015.pdf.

Ayuntamiento de Madrid, AM, 2017. Plan de Calidad del Aire de la Ciudad de Madrid y Cambio Climático (Plan A). General Directorate of Sustainability and Environmental Control, Madrid City Council 2017. http://www.madrid.es/

UnidadesDescentralizadas/Sostenibilidad/CalidadAire/Ficheros/PlanAireyCC 092017.pdf.

Ariztegui, J., Casanova, J., Valdes, M., 2004. A structured methodology to calculate traffic emissions inventories for city centres. Sci. Total Environ. 334-335, 101-109.

Beser Hugosson, M., Algers, S., Habibi, S., Sundbergh, P., 2017. Evaluation of the Swedish car fleet model using recent applications. Transport Pol. 49, 30-40. https://doi.org/ 10.1016/j.tranpol.2016.03.010.

Boogaard, H., Janssen, N.A.H., Fischer, P.H., Kos, G., Weijers, E.P., Cassee, F.R., van der Zee, S.C., de Hartog, J.J., Meliefste, K., Wang, M., Brunekreef, B., Hoek, G., 2012. Impact of low emission zones and local traffic policies on ambient air pollution concentrations. Sci. Total Environ. 435-436, 132-140. https://doi.org/10.1016/j. scitotenv.2012.06.089.

Borge, R., de Miguel, I., de la Paz, D., Lumbreras, J., Perez, J., Rodriguez, E., 2012. Comparison of road traffic emission models in Madrid (Spain). Atmos. Environ. 62, 461-471. https://doi.org/10.1016/j.atmosenv.2012.08.073.

Borge, R., Lumbreras, J., Perez, J., de la Paz, D., Vedrenne, M., de Andrés, J.M., Rodriguez, M.E., 2014a. Emission inventories and modeling requirements for the development of air quality plans. Application to Madrid (Spain). Sci. Total Environ. 466-467, 809-819. https://doi.org/10.1016/j.scitotenv.2013.07.093.

Borge, R., de la Paz, D., Lumbreras, J., Pérez, J., Vedrenne, M., 2014b. Analysis of contributions to $\mathrm{NO}_{2}$ ambient air quality levels in Madrid city (Spain) through modeling. Implications for the development of policies and air quality monitoring. J. Geosci. Environ. Protect. 2 (1), 6-11. https://doi.org/10.4236/gep.2014.21002.

Brunekreef, B., Beelen, R., Hoek, G., Schouten, L., Bausch-Goldbohm, S., Fischer, P., et al., 2009. Effects of Long-term Exposure to Traffic-related Air Pollution on Respiratory and Cardiovascular Mortality in the Netherlands: the NLCS-AIR Study. Research report (Health Effects Institute) Res Rep Health Eff Inst 2009, pp. 5-71. http://www. n65.nl/NCLS-AIR-Study-2009.pdf.

Carslaw, D.C., Beevers, S.D., Tate, J.E., Westmoreland, E.J., Williams, M.L., 2011. Recent evidence concerning higher NOx emissions from passenger cars and light duty vehicles. Atmos. Environ. 45, 7053-7063. https://doi.org/10.1016/j.atmosenv.2011. 09.063.

Curtis, L., Rea, W., Smith-Willis, P., Fenyves, E., Pan, Y., 2006. Adverse health effects of outdoor air pollutants. Environ. Int. 32 (6), 815-830. https://doi.org/10.1016/j. envint.2006.03.012.

De la Paz, D., Borge, R., Vedrenne, M., Lumbreras, J., Amato, F., Karanasiou, A., Boldo, E., Moreno, T., 2015. Implementation of road dust resuspension in air quality simulations of particulate matter in Madrid (Spain). Front. Environ. Sci. 3, 72. https://doi. org/10.3389/fenvs.2015.00072.

Degraeuwe, B., Thunis, P., Clappier, A., Weiss, M., Lefebvre, W., Janssen, S., Vranckx, S.,
2016. Impact of passenger car NOx emissions and $\mathrm{NO}_{2}$ fractions on urban $\mathrm{NO}_{2}$ pollution - scenario analysis for the city of Antwerp, Belgium. Atmos. Environ. 126, 218-224. https://doi.org/10.1016/j.atmosenv.2015.11.042.

Deka, D., 2012. The impacts of non-resident parking restrictions at commuter rail stations. J. Transport Geogr. 24, 451-461. https://doi.org/10.1016/j.jtrangeo.2012.05. 004.

Dirección General de Tráfico, DGT, 2018. Estadísticas e indicadores. Parque de vehículos: tablas estadísticas. http://www.dgt.es/es/seguridad-vial/estadisticas-e-indicadores/ parque-vehiculos/tablas-estadisticas/.

European Environment Agency, EEA, 2013. EMEP/EEA Air Pollutant Emission Inventory Guidebook-2013. EEA Technical Report No. 12/2013. . http://www.eea.europa.eu/ publications/emep-eea-guidebook-2013.

European Environment Agency, EEA, 2015a. European Union Emission Inventory Report 1990-2013 under the UNECE Convention on Long-range Transboundary Air Pollution (LRTAP). EEA Technical Report No 8/2015. https://doi.org/10.2800/031449. ISBN 978-92-9213-655-0.

European Environmental Agency, EEA, 2015b. Air Quality in Europe - 2015 Report. EEA Report. No 5/2015. https://doi.org/10.2800/62459. ISBN 978-92-9213-702-1.

European Environmental Agency, EEA, 2017. Air Quality in Europe - 2017 Report. EEA Report. No 13/2017. https://doi.org/10.2800/358908. ISBN 978-92-9213-920-9.

Ellison, R.B., Greaves, S.P., Hensher, D.A., 2013. Five years of London's low emission zone: effects on vehicle fleet composition and air quality. Transport. Res. Part D 23, 25-33. https://doi.org/10.1016/j.trd.2013.03.010.

Computer Programme to calculate Emissions from Road Transport, COPERT, 2018. http://www.emisia.com/utilities/copert/.

European Union, EU, 2008. Directive 2008/50/EC of the European Parliament and of the Council of 21 May 2008 on Ambient Air Quality and Cleaner Air for Europe. European Commission, Brussels, Belgium.

Fontaras, G., Martini, G., Manfredi, U., Marotta, A., Krasenbrink, A., Maffioletti, F., Terenghi, R., Colombo, M., 2012. Assessment of on-road emissions of four Euro V diesel and CNG waste collection trucks for supporting air-quality improvement initiatives in the city of Milan. Sci. Total Environ. 426, 65-72. https://doi.org/10. 1016/j.scitotenv.2012.03.038.

Fontes, T., Pereira, S.R., 2014. Impact assessment of road fleet transitions on emissions: the case study of a medium European size country. Energy Pol. 72, 175-185. https:// doi.org/10.1016/j.enpol.2014.04.044.

Franco, V., Sánchez, F.P., German, J., Mock, P., 2014. Real-world Exhaust Emissions from Modern Diesel Cars. A Meta-analysis of PEMS Emissions Data from EU (EURO 6) and US (Tier 2 BIN 5/ULEV II) Diesel Passenger Cars. International Council on Clean Transportation. http://theicct.org/sites/default/files/publications/ICCT PEMSstudy diesel-cars 20141010.pdf.

García, J.A., López, J.M., Lumbreras, J., Flores, M.N., 2012. Comparison of Life Cycle energy consumption and GHG emissions of natural gas, biodiesel and diesel buses of the Madrid transportation system. Energy 47, 174-198. https://doi.org/10.1016/j. energy.2012.09.052.

Hammadou, H., Papaix, C., 2015. Policy packages for modal shift and $\mathrm{CO}_{2}$ reduction in Lille, France. Transport. Res. Transport Environ. 38, 105-116. https://doi.org/10. 1016/j.trd.2015.04.008.

Hausberger, S., Rexeis, M., Zallinger, M., Luz, R., 2009. Emission Factors from the Model PHEM for the HBEFA Version 3. Graz University of Technology, Institute for Internal Combustion Engines and Thermodynamics Report Nr. I-20/2009. Haus-Em 33/08/ 679 from 07.12.2009.

HandBook of Emission Factors for Road Transport, HBEFA, 2010. Handbuch Emissionsfaktoren des Strassenverkehrs 3.1 e Dokumentation. Infras, UBA, Berlin. BUWAL, Bern/UBA, Wien. www.hbefa.net.

Jayaratne, E.R., Ristovski, Z.D., Meyer, N., Morawska, L., 2009. Particle and gaseous emissions from compressed natural gas and ultralow Sulphur diesel-fuelled buses at four steady engine loads. Sci. Total Environ. 407, 2845-2852. https://doi.org/10. 1016/j.scitotenv.2009.01.001.

Jayaratne, E.R., Ristovski, Z.D., Morawska, L., Meyer, N.K., 2010. Carbon dioxide emissions from diesel and compressed natural gas buses during acceleration. Transport. Res. Transport Environ. 15, 247-253. https://doi.org/10.1016/j.trd.2010.03.005.

López, J.M., Gómez, A., Aparicio, F., Sánchez, F.J., 2009. Comparison of GHG emissions from diesel, biodiesel and natural gas refuse trucks of the City of Madrid. Appl. Energy 86, 610-615. https://doi.org/10.1016/j.apenergy.2008.08.018.

Lozhkina, O.V., Lozhkin, V.N., 2016. Estimation of nitrogen oxides emissions from petrol and diesel passenger cars by means of on-board monitoring: effect of vehicle speed, vehicle technology, engine type on emission rates. Transport. Res. Transport Environ. 47, 251-264. https://doi.org/10.1016/j.trd.2016.06.008.

Lumbreras, J., Borge, R., Valdés, M., Rodriguez, M.E., 2008a. Assessment of vehicle emissions projections in Madrid (Spain) from 2004 to 2012 considering several control strategies. Transport. Res. Part A 42, 646-658. https://doi.org/10.1016/j.tra. 2008.01.026.

Lumbreras, J., Borge, R., de Andrés, J.M., Rodríguez, M.E., 2008b. A model to calculate consistent atmospheric emission projections and its application to Spain. Atmos. Environ. 42, 5251-5266. https://doi.org/10.1016/j.atmosenv.2008.02.067. 
Lumbreras, J., Borge, R., Guijarro, A., López, J.M., Rodríguez, M.E., 2014. A methodology to compute emission projections from road transport (EmiTRANS). Technol. Forecast. Soc. Change 81, 165-176. https://doi.org/10.1016/j.techfore.2013.02.011.

Nanaki, E.A., Koroneos, C.J., Xydis, G.A., Rovas, D., 2014. Comparative environmental assessment of Athens urban buses-diesel, CNG and biofuel powered. Transport Pol. 35, 311-318. https://doi.org/10.1016/j.tranpol.2014.04.001.

Nanaki, E.A., Koroneos, C.J., Roset, J., Suscac, T., Christensen, T.H., de Gregorio Hurtado, S., Rybkaf, A., Kopitovic, J., Heidrich, O., Amparo López-Jiménez, P., 2017. Environmental assessment of 9 European public bus transportation systems. Sustain. Cities Soc. 28, 42-52. https://doi.org/10.1016/j.scs.2016.08.025.

Ntziachristos, L., Samaras, Z., 2014. Exhaust Emissions from Road Transport - EMEP/EEA Air Pollutant Emission Inventory Guidebook - 2013. European Environment Agency.

Ntziachristos, L., Gkatzoflias, D., Kouridis, C., Samaras, Z., 2009. COPERT: a European road transport emission inventory model. Inf. Technol. Environ. Eng. 491-504. https://doi.org/10.1007/978-3-540-88351-7 37.

Pandey, A., Pandey, G., Mishra, R.K., 2016. Tailpipe emission from petrol driven passenger cars. Transport. Res. Transport Environ. 44, 14-29. https://doi.org/10.1016/j. trd.2016.02.002.

Pant, P., Harrison, R.M., 2013. Estimation of the contribution of road traffic emissions to particulate matter concentrations from field measurements: a review. Atmos. Environ. 77, 78-97. https://doi.org/10.1016/j.atmosenv.2013.04.028.

Pastorello, C., Dilara, P., Martini, G., 2011. Effect of a change towards compressed natural gas vehicles on the emissions of the Milan waste collection fleet. Transport. Res. Transport Environ. 16, 121-128. https://doi.org/10.1016/j.trd.2010.09.002.

Pérez, J., Lumbreras, J., Rodriguez, M.E., Vedrenne, M., 2017. A methodology for estimating the carbon footprint of waste collection vehicles under different scenarios: application to Madrid. Transport. Res. Transport Environ. 52, 156-171. https://doi. org/10.1016/j.trd.2017.03.007.

Pujadas, M., Núñez, L., Plaza, J., Bezares, J.C., Fernández, J.M., 2004. Comparison between experimental and calculated vehicle idle emission factors for Madrid fleet. Sci. Total Environ. 334-335, 133-140. https://doi.org/10.1016/j.scitotenv.2004.04.033.
Quaassdorff, C., Borge, R., Pérez, J., Lumbreras, J., de la Paz, D., de Andrés, J.M., 2016. Microscale traffic simulation and emission estimation in a heavily trafficked roundabout in Madrid (Spain). Sci. Total Environ. 566-567, 416-427. https://doi.org/10. 1016/j.scitotenv.2016.05.051.

Rexeis, M., Hausberger, S., 2009. Trend of vehicle emission levels until 2020 - prognosis based on current vehicle measurements and future emission legislation. Atmos. Environ. 43, 4689-4698. https://doi.org/10.1016/j.atmosenv.2008.09.034.

Rose, L., Hussain, M., Ahmed, S., Malek, K., Costanzo, R., Kjeang, E., 2013. A comparative life cycle assessment of diesel and compressed natural gas powered refuse collection vehicles in a Canadian city. Energy Pol. 52, 453-461. https://doi.org/10.1016/j. enpol.2012.09.064.

Sandhu, G.S., Frey, H.F., Bartelt-Hunt, S., Jones, E., 2014. In-use measurement of the activity, fuel use, and emissions of front-loader refuse trucks. Atmos. Environ. 92 557-565. https://doi.org/10.1016/j.atmosenv.2014.04.036.

Suthawaree, J., Sikder, H.A., Jones, C.E., Kato, S., Kunimi, H., Kabir, A.N.M.H., Kajii, Y., 2012. Influence of extensive compressed natural gas (CNG) usage on air quality. Atmos. Environ. 54, 296-307. https://doi.org/10.1016/j.atmosenv.2012.01.066.

Vedrenne, M., Pérez, J., Lumbreras, J., Rodríguez, M.E., 2014. Life cycle assessment as a policy-support tool: the case of taxis in the city of Madrid. Energy Pol. 66, 185-197. https://doi.org/10.1016/j.enpol.2013.10.073.

Vedrenne, M., Borge, R., Lumbreras, J., Rodríguez, M.E., de la Paz, D., Pérez, J., de Andrés, J.M., Quaassdorff, C., 2016. A comprehensive approach for the evaluation and comparison of emission inventories in Madrid. Atmos. Environ. 145, 29-44. https://doi.org/10.1016/j.atmosenv.2016.09.020.

Velders, G.J.M., Geilenkirchen, G.P., de Lange, R., 2011. Higher than expected NOx emission from trucks may affect attainability of $\mathrm{NO}_{2}$ limit values in The Netherlands. Atmos. Environ. 45, 3025-3033. https://doi.org/10.1016/j.atmosenv.2011.03.023.

Williams, M.L., Carslaw, D.C., 2011. New directions: science and policy - out of step on $\mathrm{NO}_{\mathrm{X}}$ and $\mathrm{NO}_{2}$. Atmos. Environ. 45, 3911-3912. https://doi.org/10.1016/j.atmosenv. 2011.04 .067 